\title{
PUESTO QUE OCUPA EL DERECHO DE DAÑOS EN EL DERECHO DE OBLIGACIONES ${ }^{1}$
}

\author{
Ricardo de Angel Yágüez \\ Catedrático de Derecho civil de la Universidad de Deusto
}

Sumario: 1. Delimitación del objeto de mi intervención: dos de las posibles interpretaciones de la expresión «puesto que ocupa». 2. Justificación de esta ponencia. 3. Emplazamiento y contenido de la regulación de la responsabilidad civil en el Código civil español. 4. Aspectos en los que se manifiesta la dualidad de regímenes de las responsabilidades contractual y extracontractual. 5. Responsabilidad contractual y extracontractual en la doctrina del Tribunal Supremo español. 6. Algunos extremos que revelan la fragilidad de la distinción entre responsabilidad contractual y extracontractual. 7. Fórmulas legales o jurisprudenciales que mitigan los rigores de la dualidad de regímenes.

\section{Delimitación del objeto de mi intervención: dos de las posibles interpretaciones de la expresión «puesto que ocupa»}

Me parece que no es temerario suponer que la ponencia que se me ha atribuido se encamina, más que a una forrnulación descriptiva (a pesar de lo que dice su título), al planteamiento de una pregunta. La pregunta sobre qué puesto debe ocupar el Derecho de daños en el Derecho de obligaciones.

Pero ni siquiera esta suposición resolvía mis problemas a la hora de determinar la orientación de la ponencia. En efecto, la expresión «puesto que осира» admite por lo menos dos interpretaciones. Tenía que optar por una de ellas. Una alternativa, por la que en fin me he decidido, con-

1 Es el texto de la ponencia presentada y expuesta por el autor en el Congreso Internacional sobre la reforma del Derecho contractual y la protección de los consumidores, celebrado en Zaragoza los días 15 a 18 de noviembre de 1993. Las actas de aquel Congreso están pendientes de publicación. 
siste en volver a plantear la dualidad responsabilidad contractual-responsabilidad extracontractual, con el propósito de proponer algunas consideraciones en torno a tan vidriosa cuestión, de la que puede decirse - utilizando lo que casi es ya un tópico- que viene atormentando a la doctrina. Se trata, en una palabra, de situar el Derecho de daños dentro del sistema de responsabilidades del Derecho de obligaciones, en búsqueda de un eventual «ámbito común» de esas dos formas de responsabilidad.

Pero otra interpretación, no menos sugestiva y comprometedora, se ofrecía como posible. En una ponencia como ésta, en la que por su generalidad he decidido no hacer uso de referencias doctrinales concretas, no puede faltar ahora, sin embargo, la cita de Genènieve Viney. Lo hago porque ella utiliza la expresión «lugar que debe ocupar», referida a la responsabilidad civil, de forma particularmente original. En el Traité de droit civil, dirigido por Ghestin, Viney plantea el fenómeno de la llamada «crisis de la responsabilidad civil». Dice la autora con razón que una de las manifestaciones de esa crisis viene constituida por las dudas referidas al fundamento de la responsabilidad civil. Pero añade que antes de tratar de esa cuestión procede plantear otra, más importante, acerca del lugar que merece ocupar esta institución y de los objetivos que debe perseguir. En otras palabras, hay que definir su papel como cuestión previa. Y así, dedica una larga exposición a lo que ella titula "Les hésitations relatives a la place que doit occuper la responsabilité civile». Bajo este epígrafe, la autora trata la sugestiva pregunta de si los sistemas de socialización directa de la indemnización pueden ocasionar un oscurecimiento de la responsabilidad civil.

El hecho de que tan autorizada especialista haya utilizado precisamente las palabras «lugar que debe ocupar» me obligaba a hacer esta observación. Y unido a esto, además, la innegable circunstancia de que el punto de vista que adopta Viney habría sido igualmente oportuno en el marco de este Congreso.

Tunc pone en relación también esas dos perspectivas cuando dice que «la distinción entre el Derecho de daños y el Derecho del contrato es tan fundamental, pero tan delicada, como la distinción entre el Derecho de daños y el Derecho de la Seguridad Social». Y además, dado que estamos especulando sobre posibles significados de la palabra «lugar», es interesante señalar que este autor, en su completo análisis de Derecho comparado sobre la responsabilidad civil (en International Encyclopedia of Comparative Law), dedica un subcapítulo a tratar «the proper place of fault in a modern law of tort». Tunc considera lógico examinar en primer lugar las funciones del Derecho de daños y, como consecuencia, el valor de la culpa como criterio de responsabilidad en la sociedad moderna. En otras palabras, la cuestión relativa a la responsabilidad por culpa versus responsabilidad basada en otros hechos o ideas. 
No obstante, como decía, me he inclinado por la primera opción. Lo he hecho así porque me parece más coherente con el título asignado a esta Sección Segunda del Congreso. Movía a pensar así, también, el hecho de que el «Derecho contractual» sea el hilo conductor de todas nuestras intervenciones. La circunstancia de que las reflexiones de Viney sean sólo sobre la responsabilidad civil las alejaba un tanto del propósito central de nuestra reunión. La palabra «lugar» en Viney tiene un significado más metafórico o más «filosófico», por así decirlo.

1. A pesar de esta elección, que por cierto me ha hecho dudar mucho tiempo, creo que es interesante sintetizar la opinión de Viney sobre esa cuestión de «emplazamiento» que ella plantea en relación con la responsabilidad civil.

Advierte la autora cómo antes de que los procedimientos modernos de socialización de los riesgos hubiesen adquirido su auge, la responsabilidad civil aparecía como la pieza maestra del sistema legal de indemnización de los daños. Su utilidad era evidente y nadie la ponía en duda. Por el contrario, cuando esos métodos nuevos se desarrollaron, la responsabilidad civil perdió el monopolio de la indemnización, aunque conservando durante mucho tiempo una preeminencia incuestionable, debida a su ambivalencia. Su función indemnizatoria estaba acompañada por una función normativa que, en el propósito de los redactores del Código civil francés, era incluso prioritaria.

En el momento actual, no puede negarse que aquella hegemonía ha sufrido una seria decadencia, hasta el punto de que en el terreno de los daños accidentales se está viendo día a día cada vez más discutida.

En todas las sociedades cuyo desarrollo económico ha permitido poner en práctica una protección social avanzada y un sistema de seguros sólido, varias orientaciones aparecen a priori como posibles para resolver las cuestiones que plantea la protección de las víctimas de los daños. El legislador puede, en efecto, elegir la ampliación del ámbito de la seguridad social y favorecer el seguro directo de ciertos perjuicios, lo que conduce a reducir la importancia del papel atribuido a la responsabilidad civil. Pero puede, por el contrario, optar en favor del desarrollo y de la extensión de la responsabilidad civil favoreciendo su práctica y su garantía a través del seguro de responsabilidad, a fin de no aumentar desmesuradamente la importancia de los procedimientos de socialización directa de los riesgos.

(Como inciso, hay que advertir que por «aseguramiento directo» Viney entiende la creación de regímenes especiales destinados a reparar ciertas clases de daños corporales, sin que sea necesario establecer responsabilidades. Sería el caso del seguro individual obligatorio contra los accidentes; ejemplo típico, el seguro obligatorio de automóvil).

A continuación, como es sabido, Viney desarrolla pormenorizadamente los siguientes extremos: en primer lugar, «la indemnización de los daños», para poner de manifiesto que no es verdad que, incluso en lo que se refiere a la extensión de la reparación, la responsabilidad civil pre- 
sente siempre una superioridad evidente en relación con los procedimientos de reparación colectiva. En segundo término, se ocupa de «la distribución de la carga de las reparaciones», extremo en el que tampoco encuentra una superioridad evidente de la responsabilidad frente a otros sistemas de indemnización. En tercer lugar, la autora analiza el papel normativo de la responsabilidad, tanto como instrumento de disuasión de comportamientos antisociales (bien sea en el plano individual, bien a escala de la colectividad), así como para la «afirmación» de ciertos derechos, en el sentido de búsqueda de medios para hacerlos respetar.

A renglón seguido, Viney examina la variedad de las respuestas dadas al problema de la concurrencia entre la responsabilidad civil y procedimientos de socialización directa de los riesgos, analizando en detalle dos sistemas. En primer lugar, el de ampliación de la seguridad social a costa de la responsabilidad civil. Y en segundo término, la sustitución de la responsabilidad civil por un sistema de seguro individual obligatorio contra los accidentes.

La conclusión a la que llega Viney, ya lo saben ustedes, es la de que, a pesar de las objeciones de que ha sido objeto en los últimos tiempos, la responsabilidad conserva, todavía hoy, una vitalidad real; aunque es evidente que entre esta responsabilidad moderna y la que habían concebido los redactores del Código civil francés la distancia es inmensa.

Esta apretada síntesis que acabo de hacer no es sino homenaje a las brillantes reflexiones de nuestra colega francesa, y por haberlas hecho, precisamente, bajo una rúbrica que coincide con el título asignado a mi intervención. Por otro lado, es tranquilizador para mí el hecho de que la misma autora utilice también, curiosamente, la expresión «lugar» cuando somete a análisis la distinción entre responsabilidad contractual y extracontractual. En efecto, Viney termina ese análisis refiriéndose a lo que ella llama «estudio crítico del lugar ocupado por la distinción entre las responsabilidades contractual y delictual».

2. Por otro lado, procede una puntualizacion terminológica. Aunque el título de la ponencia habla de «Derecho de daños» (expresión de evidente procedencia anglosajona que cada día encuentra más arraigo en la doctrina española), nosotros vamos a utilizar indistintamente las de «responsabilidad civil»y «responsabilidad extracontractual». Esta última, desde luego, en el sentido que se le atribuye en Derecho español, no del todo coincidente con lo que las palabras dicen: innecesario es advertir que existen obligaciones legales (legal duties en terminología inglesa) que no son subsumibles en la clásica denominación de «responsabilidad civil».

\section{Justificación de esta ponencia}

Como antes he indicado, voy a dedicar mi atención a lo que a mi juicio constituye una de las mayores incertidumbres cuando nos planteamos la cuestión relativa al emplazamiento y contenido de la responsabilidad 
civil, esto es, la que resulta de la clásica dualidad de regímenes entre ella y la responsabilidad contractual.

Desde el punto de vista conceptual, el binomio a que me refiero puede formularse con cierta precisión. La responsabilidad extracontractual dimana de la violación de deberes generales de abstención, omisión o no injerencia; la contractual, por el contrario, resulta del incumplimiento, en sentido amplio, de los deberes derivados de una obligación preexistente, incluyendo los deberes accesorios de conducta en el marco de la compleja relación obligacional. Sin embargo, como se ha puesto de relieve por los autores, ambas categorías no constituyen, sobre todo en la práctica, compartimentos estancos. Me parece particularmente afortunada la afirmación de que en no pocos aspectos la responsabilidad contractual y extracontractual funcionan como verdaderos vasos comunicantes. Por ejemplo, la definición de cuáles sean los deberes accesorios de conducta dentro de una relación contractual es tan sumamente controvertida que no cabe hacer de ella más que una formulación genérica que da pie a las más notables divergencias en su aplicación a los casos concretos.

En una palabra, la distinción está llena de «zonas grises», en las que la tarea de calificación resulta particularmente complicada.

Que esta dificultad no es privativa de un sistema jurídico concreto, sino prácticamente universal, lo pone de relieve la circunstancia de que dos capítulos de los dos volúmenes dedicados a Torts en International Encyclopedia of Comparative Law se refieran casi exclusivamente a esta cuestión. En el capítulo 1 (Introduction), Tunc dedica un considerable apartado a la distinción entre tort y contract. Se ponen allí de relieve los problemas que derivan de esta distinción, que, dice Tunc, «puede justificar un cierto escepticismo hacia ella» $\mathrm{y}$ «ha sido atacada por artificial». Señala el autor cómo por ejemplo en los países del common law ha sido denunciada la «incertidumbre» del criterio de distinción o su «relatividad». Se pone el énfasis en los serios inconvenientes prácticos de esta dualidad, apuntando Tunc la cuestión acerca de la «concurrencia» de responsabilidades. Y en el volumen 2 del tomo XI, todo un capítulo (el 12), versa sobre las «complex liabilities» esto es, los extremos en los que las obligaciones delictuales y contractuales difieren en varios sistemas legales, así como sobre los problemas procesales que de esa distinción derivan (Weir).

En la doctrina inglesa, recientemente, se ha vuelto a insistir en la importancia del problema, señalándose que la elección entre las reglas contractuales o extracontractuales (por parte del demandante) se ha llevado a cabo de una forma que, aunque históricamente explicable, «estaba cerca de ser caprichosa» (Dias y Markesinis). Estos autores dicen que la reciente tendencia de permitir a los demandantes la elección entre las acciones contractuales y extracontractuales debe considerarse como un movimien- 
to hacia la atenuación de las diferencias entre contrato y daño; al igual que los más modernos intentos de aproximar las reglas sobre la remoteness of damage.

No es que deba extrañarnos, como juristas, que el éxito o el fracaso de una demanda pueda estar condicionada por una correcta o incorrecta calificación del supuesto de hecho. Muy al contrario, sabemos que en calificar adecuadamente una species facti, cuando se trata de resolver un conflicto, o de ejercitar un derecho, consiste una de las reglas del juego del orden jurídico.

No obstante, en el caso que nos ocupa creo que no resiste la más elemental crítica el hecho de que el desenlace de la reclamación se vea sujeto a una calificación en la que el actor, de antemano, opta por una determinada acción sobre la base de elementos de juicio, criterios, rasgos y caracteres en los que de ordinario la jurisprudencia, así como la doctrina, navegan en un mar de dudas, ambigüedades, casuismos e incluso no pocas veces contradicciones. Es aquí donde uno tiene la impresión de que se tambalea la seguridad jurídica y de que el valor de la certeza del Derecho corre el riesgo de convertirse en un auténtico juego de azar, esto es, en una simple suerte en la elección; en suma, en lo que a posteriori, por definición, pueda considerar el tribunal que es haber acertado.

No menos graves son las contradicciones (a veces auténticos absurdos) a que lleva la aplicación de un determinado régimen de responsabilidad en cuanto a una víctima y la de otro régimen a una víctima diferente, tratándose del mismo acontecimiento.

Es habitual entre los autores la cita, en cuanto a este último extremo, del jocoso comentario que hizo Esmein del caso llamado «caída en una escalera». Según si la víctima es un arrendatario o un extraño, la responsabilidad del propietario se califica como contractual o delictual. Las posibilidades de indemnización de la víctima pueden ser radicalmente diferentes, en atención a la llamada «obligación contractual de seguridad» que corresponde al arrendador respecto al arrendatario. Creo - decía el autor- que es inaceptable hacer responsable al propietario de forma diferente en relación con el arrendatario que en lo que se refiere a terceros que se caen en la escalera; aquél debe mantenerla en buen estado para con todos los que están en condiciones de utilizarla. Decía Esmein que dudaba de una doctrina jurídica que él no pudiera hacer entender a los justiciables.

Este absurdo se ilustra también por Viney con ejemplos como el de «la botella que explota», «el resbalón sobre el suelo» y las «sorpresas que reserva la entrada en una estación». Alude el primer caso a la explosión de una botella en un almacén; si daña a un cliente que pasaba por allí, la responsabilidad del comerciante es delictual; pero si la botella explota en- 
tre las manos de un cliente que la ha tomado de las estanterías con intención de comprarla, la responsabilidad del propietario del almacén se plantea sobre la base de una obligación contractual de seguridad. Este es un caso, por cierto, que encontramos también en la jurisprudencia española. El segundo supuesto, el del resbalón producido en un establecimiento, también es chocante: la víctima deberá colocarse en el terreno de la responsabilidad delictual porque el tendero no está obligado por ninguna obligación contractual de seguridad en relación con eventuales clientes; pero será de otro modo si el resbalón se produce en el vestíbulo de un hotel, cuyo propietario sí se considera que está sujeto a una obligación contractual de seguridad. Se da la circunstancia de que también esta segunda hipótesis constituye un caso de nuestra propia jurisprudencia. En cuanto a la entrada en una estación, el caso es el siguiente: si una mujer acompaña a la estación a su marido, que va a tomar el tren, y los dos son atropellados en el andén por una carretilla, el marido podrá ampararse en la existencia de una obligación contractual, en concreto una de las llamadas «de seguridad»; pero la mujer, en su calidad de tercero, interpretará su percance al amparo de la responsabilidad extracontractual; salvo que, como apunta con ironía Viney, estuviese provista de un «billete de andén», en cuyo caso su condición sería exactamente la de su esposo.

El contraste es tanto más llamativo cuanto que, como pone de relieve Giardina, un caso de «resbalón a causa de hojas de ensalada», al igual que dos de «explosión de botellas», fueron resueltos (en Francia) en términos de responsabilidad contractual, a partir de la idea de una obligation de sécurité. Mientras que se apreció responsabilidad extracontractual en el caso de caída de un cliente a causa de «restos de pastelería».

Creo que no exagero al decir que la distinción entre una y otra formas de responsabilidad constituye la cuestión que (desde el punto de vista del «sistema») más debe inquietar al estudioso de la responsabilidad civil. Aun consciente de que puede ser opinión no compartida por ustedes, me atrevo a adelantar la mía: pienso que la dualidad de regímenes de responsabilidad (al menos en su expresión más rigurosa) constituye una de las manifestaciones más patentes de sometimiento de la justicia material al conceptualismo. En otras palabras, de sacrificio de las soluciones razonables en el altar de la dogmática.

La doctrina de los países europeos de tradición romano-francesa, así como la de los de estirpe germánica, pone de manifiesto que la distinción en que nos hallamos suscita las mayores inquietudes desde el punto de vista de la aplicación práctica del Derecho. Ocurre esto incluso en Austria, cuyo ordenamiento jurídico no hace ninguna distinción entre contrato y daño extracontractual a efectos de su reparación. El parágrafo 1.295 de su Código civil determina que «una persona está legitimada para demandar indemnización del daño a aquella otra que le haya causado un perjuicio 
por su culpa; el daño — añade el precepto — debe haber sido causado bien por la violación de un deber contractual, bien al margen de un contrato». Es sabido que los redactores del Código civil austríaco no intentaron establecer un dualismo de regímenes en torno a responsabilidad contractual y extracontractual. Pero eso no obsta para que la doctrina de aquel país señale que hay un buen número de importantes diferencias sobre los fundamentos y alcance de la responsabilidad, según si el daño se ha causado dentro de una relación contractual o no. Esas diferencias se refieren sobre todo a tres puntos: en primer lugar, a las reglas sobre carga de la prueba de la culpa; en segundo término, a los criterios en torno a la responsabilidad por hecho ajeno; y en fin, a la cuestión de si son o no indemnizables las pérdidas económicas que no sean consecuencia de una lesión a la persona o a la propiedad del demandante (es decir, los pure economic losses en terminología del common law).

En el Derecho inglés, por otra parte, se dice tradicionalmente que la distinción entre contract y tort es la de que en el segundo caso la responsabilidad deriva de un deber impuesto a todas las personas de forma general por la ley, mientras que los deberes contractuales tienen su origen en el acuerdo entre ambas partes, es decir, son definidas por el propio acuerdo y sólo vinculan a las partes mismas. Pero advierten los autores que si hay situaciones que claramente pertenecen al terreno exclusivo de uno u otro fundamentos de la responsabilidad, hay otros muchos casos en que la explicación de la distinción sólo puede mantenerse con la ayuda de una buena dosis de ficción. Se señala que muchos deberes contractuales derivan nominalmente del «agreement», porque se basan en los términos «implícitos» en el contrato, aun cuando las partes no hayan pensado en el asunto. En suma, se acepta como inevitable el hecho de que contract y tort se solapan, en el sentido de que un mismo conjunto de acontecimientos puede dar lugar a obligaciones de ambas naturalezas. Y aunque en términos generales se reconoce que el actor puede demandar por uno u otro conceptos (nunca ser indemnizado por ambos a la vez), la dualidad de regímenes es también motivo de radical discusión para los autores y para la propia jurisprudencia.

Creo que es explicable la búsqueda de una solución clara. No parece ni razonable ni justo que lo que para el jurista teórico es una sugestiva disquisición técnica, en la que a veces puede encontrar el atractivo de una constante puesta en juego de su imaginación (en definitiva, casi un divertimento), constituya sin embargo (en la práctica) un obstáculo tan notoriamente desproporcionado (y alguno diría que sin sentido) para el éxito de una pretensión materialmente fundada.

Si se admite que el Derecho no está para introducir dificultades innecesarias en la vida social, sino justamente al contrario, para eliminar las evitables, encuentran pleno fundamento, a mi juicio, los intentos doctrinales de poner coto a esta situación 
No necesariamente en 1a línea de establecer un régimen unitario como el que se ha seguido en el Código civil de Quebec de 1991, o en el de uno de los proyectos de modificación del Libro II del Código civil argentino, actualmente en curso, sino en la línea de dejar en lo estrictamente imprescindible las consecuencias prácticas de la distinción.

Y vaya por delante mi opinión de que muchos factores, entre ellos la abundancia de aspectos que relativizan la distinción que nos ocupa (a los que luego me referiré), permiten sostener que la aproximación de regímenes es probablemente muy fácil en el terreno sustantivo. Y las diferencias en el orden procesal son también en buena medida superables.

No es necesario encarecer el relieve que al problema que nos ocupa están dando todos los autores. Se trata de extremo particularmente analizado en las obras generales y en las monográficas sobre responsabilidad civil. Y es significativo, por ejemplo, que en España se hayan publicado en los dos últimos años dos monografías cuyo objeto es exclusivamente esta distinción (Cavanillas Múgica y Tapia Fernández, de un lado, e Yzquierdo Tolsada de otro). Y en Italia acaba de publicarse otro libro sobre la materia (Giardina).

En la doctrina inglesa, sin embargo, algunos autores que escriben sobre torts se adentran directamente en su estudio, sin ponerlo en relación con los daños contractuales. Así, en Law of Torts de Salmond y Heuston.

\section{Emplazamiento y contenido de la regulación de la responsabilidad civil en el Código civil español}

Siguiendo el criterio del Código civil italiano de 1865, el español atribuye al acto ilícito dañoso la condición de una de las fuentes de las obligaciones, junto con la ley, los contratos y los cuasicontratos. En definitiva, la perspectiva del Código civil francés, aunque en él no exista un elenco de fuentes.

Igual sucede en el área del common law, si bien en ella la idea de fuente de la obligación no reviste el significado rector que es propio de los ordenamientos continentales.

Pero nuestro Código se aparta del Code en que no toma como referencia el carácter doloso o culposo de la conducta (el délit y el quasi-délit), sino la circunstancia de que el comportamiento sea o no constitutivo (además) de un ilícito penal (delito o falta).

El artículo 1.089 incluye entre las fuentes de las obligaciones «los actos y omisiones ilícitos o en que intervenga cualquier género de culpa o negligencia», distinción que no es puramente conceptual sino que —quizá convenga ponerlo de relieve ante nuestros colegas extranjeros- determina otra adicional dualidad de regímenes, como es el de la responsabilidad 
por acto ilícito constitutivo de delito frente al del que no lo es. Hay que hacer notar que según el artículo 1.092 de nuestro Código las obligaciones civiles que nacen de los delitos o faltas se rigen por las disposiciones establecidas al efecto en el Código penal. Se trata de una diversidad anacrónica y unánimemente criticada, que no obstante se mantiene. El hecho de que los tribunales penales resuelvan de ordinario (también) sobre la responsabilidad civil derivada del delito (a veces incluso cuando la sentencia penal propiamente dicha es absolutoria), unido a la circunstancia de que existan ciertas divergencias — no pequeñas - entre el régimen de responsabilidad civil del Código civil y el del Código penal (la mal llamada «responsabilidad civil ex delicto»), da lugar a considerables y absurdos problemas de interpretación que todos deseamos ver eliminados para siempre.

Es circunstancia notable en la reglamentación de la responsabilidad civil por parte de nuestro Código civil (artículos 1.902 a 1.910) —igual por cierto que en el Code- el hecho de que la totalidad de los preceptos se encaminan a lo que podríamos llamar «la descripción del hecho dañoso», partiendo de una fórmula de numerus apertus o «cláusula general» similar a la del artículo 1.382 del Código civil francés, esto es, en línea distinta de la que adopta por ejemplo el BGB. Quiero decir que llama la atención el hecho de que ni un solo precepto, en aquel lugar del Código, se refiera a los elementos característicos del ilícito (antijuridicidad y culpabilidad) - $\mathrm{o}$ en su caso a las causas de exclusión de dichos elementos-, ni al daño y sus clases, ni al contenido o al alcance del deber de indemnizar, ni a reglas sobre legitimación para demandar, etc.

Parece, por tanto, como si nuestro legislador hubiese querido dejar en blanco todas esas cuestiones, a expensas de su interpretación jurisprudencial y sobre la base de un principio de amplia libertad de criterio. Pero también cabe la tesis de que el Código hace una implícita remisión a las reglas que sobre la culpa y el daño (y su reparación) se contienen en sede de responsabilidad contractual, es decir, en los artículos 1.104 a 1.107. De hecho, la jurisprudencia del Tribunal Supremo ha acudido frecuentemente a este segundo camino por medio de la analogía.

\section{Aspectos en los que se manifiesta la dualidad de regímenes de las responsabilidades contractual y extracontractual}

La doctrina y la jurisprudencia vienen poniendo de relieve los aspectos más significativos de esta dualidad de regímenes de que hablamos. Esta dualidad, no lo olvidemos, sería en todo caso consecuencia de una diversidad previa, cual es la consistente en que la fuente de una y otra responsabilidades es diferente: el contrato en un caso; en el otro la ley. 
Aquí es donde probablemente radica la debilidad del sistema, porque - como bien se ha dicho- parece claro que la solución de este delicado problema de distribución en sectores no puede ser situada acríticamente en las tradicionales distinciones escolásticas. No puede ser satisfactorio ampararse sólo en la diversidad de fuentes de las dos responsabilidades para justificar su diversidad de régimen. Y por otra parte, parece elíptico valorar la diversidad de regímenes — con fines aparentamente descriptivos-, para luego justificarla a posteriori por medio de la diversidad de fuentes.

Quizá, por ello, el razonamiento adolezca del vicio que en Lógica se conoce por petición de principio, sin perjuicio de que también haya jugado su papel la inclinación a la simetría que es característica del pensamiento jurídico y que Rodotà expresó como «seducción del espíritu geométrico». Esa seducción tendría mucho que ver con una cierta analogía de secuencias en la regulación legal de una y otra responsabilidades. Pero el mismo autor advierte que de esa aparente analogía no es posible deducir también conclusiones de carácter estructural, porque cambian los puntos de partida de una y otra secuencia: en la hipótesis de la responsabilidad contractual, la ley, partiendo del incumplimiento, ha definido ya el criterio de individualización del sujeto responsable; mientras que en la otra hipótesis la distinta relevancia jurídica de las situaciones de las que se parte (el hecho dañoso) hace que el problema previo sea la definición del criterio en base al cual se hacen gravitar sus consecuencias sobre un sujeto determinado.

\section{A) Se advierten algunas diferencias sustantivas o materiales}

1. En primer lugar, en lo que se refiere a la culpa. Al igual que ocurre en Francia, por ejemplo, en España se ha sostenido que una diferencia característica del sistema de responsabilidad contractual, respecto de la extracontractual, reside en el grado de gravedad de la culpa. Mientras que en la extracontractual, de acuerdo con esquemas clásicos, se ha afirmado que la culpa más ligera (la culpa levísima) da lugar a responsabilidad, en materia de responsabilidad contractual sólo la culpa levis podría acarrearla.

Ahora bien, del mismo modo que en Francia se ha puesto de relieve que esta diferencia no debe ser exagerada (sobre todo si se tiene en cuenta la relativa facilidad con que la jurisprudencia admite en materia contractual la existencia de culpas leves), en España algunas orientaciones doctrinales — con cierto reflejo jurisprudencial — han sometido a revisión el criterio tradicional que atribuye responsabilidad al deudor cuando el incumplimiento es sólo consecuencia de su culpa.

En efecto, aunque en materia de responsabilidad contractual la doctrina y la jurisprudencia españolas se encuentran situadas, con carácter predominante, en lo que se puede llamar la línea subjetivista tradicional, esto es, aquella según la cual la responsabilidad del deudor supone no sólo un objetivo incumplimiento de la obligación, sino que ese incumplimiento 
sea culpable, no es posible silenciar la opinión doctrinal que sostiene que la culpa no es el único fundamento de esta responsabilidad, puesto que el deudor responde, incluso sin culpa, cuando no puede probar un caso fortuito liberatorio (Díez-Picazo).

En punto al elemento «culpa», en otro tiempo se jugó también (como expresión de la diversidad de regímenes de ambos tipos de responsabilidad) con la distinción entre apreciación de la culpa del agente en abstracto o en concreto Sin embargo, este criterio diferencial no ha gozado de gran éxito ni en la doctrina ni en la jurisprudencia y es oportuno señalar que en Portugal, por ejemplo, ya no tiene significado alguno. El artículo 799.2 del Código civil portugués identifica el tratamiento de ambas modalidades de culpa.

2. En segundo término, distinto es, al menos según una opinión muy argumentada, el alcance del deber de reparar. Se razona que si todo contrato supone una específica distribución de riesgos entre las partes, imputable a su autonomía privada, esta circunstancia debe reflejarse en el régimen jurídico de la responsabilidad por el incumplimiento de las obligaciones nacidas del contrato, sin que quepa extenderlo a la responsabilidad extracontractual y en general a las obligaciones que tienen su origen en la ley.

El artículo 1.107, que formal o sistemáticamente es un desarrollo del 1.101 (precepto este último que consagra el principio de responsabilidad por el incumplimiento, o por el cumplimiento defectuoso o tardío de las obligaciones contractuales), dispone en su párrafo primero que «los daños y perjuicios de que responde el deudor de buena fe son los previstos o que se hayan podido prever al tiempo de constituirse la obligación y que sean consecuencia necesaria de su falta de cumplimiento». Y añade su párrafo segundo que «en caso de dolo responderá el deudor de todos los (daños y perjuicios) que conocidamente se deriven de la falta de cumplimiento de la obligación».

Pues bien, precisamente en el criterio de la previsibilidad del daño al tiempo de contratar, como límite del quantum respondatur en materia de responsabilidad contractual, se basa la opinión de que aquel precepto no es aplicable al ámbito de la extracontractual (Pantaleón).

Sostiene este autor que la explicación jurídico-económica de que el «fin de protección del contrato» se limite a los daños previstos o previsibles al contratar es fácil de comprender. La decisión de celebrar un contrato descansa en un cálculo de costes-beneficios, más o menos consciente, de cada una de las partes contratantes, siendo uno de los costes a tener en cuenta el relativo al riesgo de que se produzcan una serie de daños a consecuencia de un eventual incumplimiento. No tendría buen sentido - diceque el contratante que resulte incumplidor debiera responder de aquellos 
resultados dañosos que ni contempló como posibles en el momento de celebrar el contrato, ni una persona razonable, al tiempo de contratar, y contando con los especiales conocimientos de aquél, habría previsto que pudieran producirse a consecuencia de tal incumplimiento.

Se observa que Pantaleón hace una implícita invocación al criterio de la «finalidad protectora de la norma» como uno de los posibles para llevar a cabo la imputación de un resultado, esto es, lo que se ha venido entendiendo como problema de relación de causalidad. Y no está de más señalar, de paso, que ese criterio ha sido expresamente recogido en el Código civil holandés, cuyo artículo 163 del Libro 6 dispone que «la obligación de reparación no existe cuando la norma transgredida no tiene por objeto la protección contra un daño como el sufrido por la víctima».

Siguiendo su análisis de la proposición primera del artículo 1.107, Pantaleón defiende su restricción al ámbito de las obligaciones nacidas del contrato sobre la base de que un rasgo característico de las obligaciones legales es que el deudor puede no tener conocimiento de la realización del hecho constitutivo de su obligación e ignorar, por tanto, su condición de tal. Y se pregunta: ¿Qué daños prevé o puede prever, al tiempo de constituirse la obligación, como posibles consecuencias de la falta de cumplimiento de la misma, alguien que en dicho momento ni siquiera sabe que está obligado?

No obstante, no faltan opiniones en sentido distinto y la jurisprudencia no es muy esclarecedora al respecto.

Por el contrario, es comúnmente admitido que el artículo anterior (1.106), en cuanto determina el contenido de la obligación de indemnizar, como cosa distinta de su alcance, sí es aplicable a los casos de responsabilidad extracontractual. Se dice en ese artículo que «la indemnización de daños y perjuicios comprende no sólo el valor de la pérdida que haya sufrido, sino también el de la ganancia que haya dejado de obtener el acreedor»; en suma, el binomio damnum emergens-lucrum cessans.

3. Otro aspecto en el que se muestra en nuestro Derecho la distinción entre ambas formas de responsabilidad es el relativo a la prescripción en un caso y en otro.

Las acciones personales que no tienen señalado término especial prescriben a los 15 años (artículo 1.964); entre ellas, la de indemnización de daños por incumplimiento o cumplimiento defectuoso del contrato. Por el contrario, la acción para exigir la responsabilidad civil prescribe por el transcurso de un año (artículo 1.968).

Tan notab1e diferencia (que se da también en otros ordenamientos europeos) constituye en la práctica uno de los motivos de mayor zozobra para el jurista práctico, haciendo que la calificación a priori de un determinado supuesto de hecho se convierta en uno de los más inquietantes desafíos. 
4. Otra diferencia que tradicionalmente se ha invocado es la que se refiere al régimen de responsabilidad en el caso de concurrencia de varios agentes.

En materia de responsabilidad contractual, el Código civil español, a diferencia de lo que ocurre en algún otro europeo, se inclina por la fórmula de la no presunción de solidaridad, esto es, la de la mancomunidad (o en denominación más correcta, responsabilidad parciaria o pro parte). Principio que, no obstante, está siendo objeto de considerables salvedades (en definitiva, excepciones) por parte del Tribunal Supremo.

Por el contrario, en materia de responsabilidad extracontractual nuestros tribunales, después de vacilaciones iniciales, vienen optando por la solidaridad cuando varias personas concurren como autores en la producción de un daño.

Fenómeno similar se ha producido en Francia, puesto que aunque en su Código la solidaridad no se presume, la jurisprudencia, hace ya tiempo, resolvió que los corresponsables quedan obligados solidariamente. Más recientemente, sin embargo, la jurisprudencia ha considerado que existe solamente una obligación in solidum, lo que excluye los llamados «efectos secundarios» de la solidaridad.

5. También puede influir la diferente calificación de un caso a efectos del seguro. No es infrecuente que las pólizas «de responsabilidad» (en sentido amplio) otorguen una determinada calificación al riesgo objeto de cobertura, circunstancia en la que puede estar en juego no sólo el interés del asegurado, sino también el de la víctima. Sobre todo cuando - como ocurre en Derecho español - este último goza de acción directa contra la aseguradora para reclamar de ella la correspondiente indemnización. Pero estimo que aquí el problema es fácilmente superable, partiendo del principio de que la función calificadora del juez se sobrepone a la que hayan hecho las partes («un contrato es lo que es y no como las partes lo hayan denominado»).

Luego me referiré a un caso de la jurisprudencia española en el que probablemente se forzó de forma innecesaria (en favor de la víctima) el significado de lo que entendemos por «obligaciones contractuales».

\section{B) Pero tan grave como esta dualidad de regímenes en el plano sustantivo es la que existe en el aspecto procesal}

1. La diferencia se proyecta, por ejemplo, en lo que se refiere a la «formulación de la causa petendi», esto es, el fundamento de la acción, cuando dentro de este concepto se incluye la cita de las normas jurídicas en que aquélla se basa. 
Luego me referiré a lo que acontece en algunos países y a lo que viene declarando últimamente nuestro Tribunal Supremo. Pero por ahora interesa, a mi juicio, señalar que la expresión de la causa petendi no es un fin en sí mismo sino un instrumento para garantizar la rectitud del proceso y el adecuado ejercicio del derecho de defensa por parte del demandado.

Me remito al acertado y completo análisis que se hace de esta cuestión en la monografía de Cavanillas y Tapia.

2. También reviste dificultad, ciertamente, el problema relativo a la competencia judicial territorial para conocer de uno y otro casos de responsabilidad. En efecto, el artículo 62, regla 1.a, de nuestra Ley de Enjuiciamiento civil determina que el juez competente para conocer de las acciones personales (entre las que se encuentra la de responsabilidad contractual) es, en primer término, el del lugar en que deba cumplirse la obligación; y a falta de éste, a elección del demandante, el del domicilio del demandado o el del lugar del contrato. Por el contrario, es principio jurisprudencial ya asentado en materia de responsabilidad extracontractual el de que el juez competente para conocer de ella es el del lugar en que ocurrió el hecho dañoso; es decir, el criterio tradicional del forum delicti commissi.

3. No menos notable es la divergencia en nuestras normas de Derecho internacional privado. Las obligaciones contractuales quedan sujetas a la ley a que las partes se hayan sometido expresamente, siempre que tenga alguna conexión con el negocio de que se trate; en su defecto, se aplicará la ley nacional común a las partes; a falta de ella, la de la residencia habitual común; y en último término, la ley del lugar de celebración del contrato (artículo 10.5). Mientras que las «obligaciones no contractuales» se regirán por la ley del lugar donde hubiere ocurrido el hecho de que deriven (artículo 10.9).

4. Por otra parte, no es posible silenciar el alcance que el binomio responsabilidad contractual-responsabilidad extracontractual tiene en el llamado "Derecho internacional privado convencional», esto es, en las normas de conflicto contenidas en tratados internacionales. Y esto, tanto en lo que respecta a la competencia judicial internacional como a la ley aplicable a una determinada controversia.

1. Por lo que se refiere al primero de esos dos aspectos, es inevitable la mención del Convenio de Bruselas sobre competencia judicial y ejecución de resoluciones judiciales en materia civil y mercantil, de 27 de setiembre de 1968, con las adaptaciones introducidas por el Convenio de 9 de octubre de 1978 (adhesión por parte de Dinamarca, Irlanda y Gran Bretaña), por el de 25 de octubre de 1982 (adhesión de Grecia) y por fin 
por el de 26 de mayo de 1989 (Convenio de San Sebastián), relativo a la adhesión de España y Portugal al pacto primitivo.

A los efectos que nos ocupan, repárese en que el artículo 5 del Convenio establece en materia contractual la competencia del tribunal en el que hubiere sido o debiere ser cumplida la obligación, mientras que en materia delictual o cuasidelictual es competente el tribunal del lugar donde se hubiere producido el hecho dañoso.

Debe también tenerse presente el contenido de la Sección 4 del Título II, en su actual redacción (artículos 13 a 15), sobre «competencia en materia de contratos celebrados por los consumidores». Aunque en esta materia — consumo - es donde se han producido los fenómenos más visibles de «superación» del binomio responsabilidad contractual-responsabilidad extracontractual, según luego veremos, hay que hacer notar, no obstante, que los mencionados preceptos del Convenio se refieren sólo a supuestos en que el consumidor ejercita su acción contra quien ha contratado con él, esto es, en la órbita contractual. Así resulta de la rúbrica de la Sección en que se emplaza este artículo y de la propia redacción de los artículos 13 y 14 .

2. En lo que respecta a ley aplicable es interesante el Convenio de 2 de octubre de 1973, de La Haya, sobre ley aplicable a la responsabilidad por productos, ratificado por España por instrumento de 7 de noviembre de 1978, así como el Convenio sobre la ley aplicable a las obligaciones contractuales, abierto a la firma en Roma el 19 de junio de 1980, en el marco de la Comunidad Económica Europea. España y Portugal se adhirieron por Convenio de 18 de mayo de 1992, ratificado por España el 7 de mayo de 1993.

El primero de esos Convenios tiene la particularidad de que determina la ley aplicable a las reclamaciones entabladas por el consumidor por vía de responsabilidad extracontractual, dado que según el artículo 1, párrafo segundo, cuando hubiere sido transferida la propiedad o el disfrute de un producto a la persona que sufre el daño por aquella a quien se imputa la responsabilidad, no se aplicará el Convenio a las relaciones entre las mismas. En ellas (típico caso de responsabilidad contractual) regirá, por tanto, la ley del contrato que liga al imputado o presunto responsable con la víctima.

En cuanto al segundo de los Convenios citados, su propia denominación («ley aplicable a las obligaciones contractuales») pone de manifiesto que también en este punto se hace inevitable acudir a la distinción que nos ocupa, como presupuesto para una correcta invocación de las normas de conflicto que el propio Convenio contiene. Como es sabido, son: en primer lugar, sometimiento a la ley elegida por las partes —artículo 3-; y en segundo lugar, a falta de elección, «ley del país con el que el contrato presente los vínculos más estrechos» —artículo 4-. Sin perjuicio, claro está, de la particularidad establecida para los «contratos celebrados por los consumidores» - artículo 5- Hay que hacer notar que no elimina la necesidad de calificar, sino que la presupone, el artículo 10 de este Convenio. Refiriéndose al «ámbito de la ley del contrato», dicho precepto dice que esa ley aplicable regirá en particular «el cumplimiento de las obligaciones que genere el contrato» y las consecuencias del incumpli- 
miento total o parcial de estas obligaciones, dentro de los límites de los poderes atribuidos al tribunal por sus leyes procesales (ap. 1, b y c). Al menos a la luz de nuestra jurisprudencia, definir hasta dónde llegan las «obligaciones contractuales», como frontera respecto de la responsabilidad extracontractual, es cuestión notablemente complicada.

5. Se ha solido invocar como expresión de la diferencia de régimen el extremo relativo a la prueba de la culpa.

La doctrina y la jurisprudencia dominantes estiman que al acreedor le basta la alegación del incumplimiento de la obligación, presumiéndose la culpa del deudor por aplicación analógica del artículo 1.183. Sobre el deudor recae, por tanto, la carga de probar las causas por las que el incumplimiento no le es imputable. Frente a esto - se adujo en el pasado- en el ámbito de la responsabilidad extracontractual recae sobre el perjudicado demandante la prueba de la culpa del agente.

Pero en la actualidad, consistentemente instalado ya en nuestro país el principio jurisprudencial de inversión de la carga de la prueba en materia de responsabilidad civil, este criterio de diferenciación carece de sentido.

A título de ejemplo, en la más reciente bibliografía, Carbonnier (en la francesa) establece las siguientes diferencias entre las dos clases de responsabilidad: a) la extracontractual es menos exigente, en relación con algunos de sus presupuestos; b) la puesta en mora es necesaria en la contractual, pero no en la extracontractual; c) los convenios de irresponsabilidad serían nulos en la extracontractual, no en la contractual; d) la solidaridad constituye la regla en la extracontractual, mientras que en la contractual el régimen normal es la mancomunidad; e) sólo la responsabilidad extracontractual está sujeta a la prescripción de plazo corto; f) la carga de la prueba funciona en términos diferentes en una y otra clase de responsabilidades.

También hace poco, en Italia, Giardina menciona las siguientes diferencias, que en el pasado se tuvieron por indiscutibles: a) en primer lugar, el hecho ilícito podría violar solamente un derecho absoluto, mientras que el incumplimiento lesionaría un derecho dc crédito; b) en las dos figuras de responsabilidad existiría una distinta configuración de la carga de la prueba; c) las cláusulas de exoneración de responsabilidad serían lícitas, dentro de ciertos límites, únicamente para la responsabilidad contractual; d) en cuanto a los daños, la responsabilidad extracontractual implica la reparación de todos los previsibles e imprevisibles, siempre que sean consecuencia inmediata y directa del hecho ilícito, mientras que la responsabilidad contractual obliga al deudor a resarcir sólo los daños previsibles en el momento de constituirse la obligación, salvo que el incumplimiento resulte de dolo; e) el daño moral únicamente sería admisible en materia de responsabilidad extracontractual; f) los plazos de prescripción son distintos, dando una protección más amplia al interés del acreedor perjudicado en el ámbito de la responsabilidad contractual. 


\section{Responsabilidad contractual y extracontractual en la doctrina del Tribunal Supremo español}

Nuestra jurisprudencia (sin perjuicio de la fórmula amortiguadora a que luego voy a referirme) sigue apegada a la distinción.

El Tribunal Supremo tiene dicho:

a) Son netamente diferenciables los regímenes de las responsabilidades contractual y extracontractual.

b) Las diferencias que caracterizan los respectivos regímenes giran principalmente en torno a su distinto origen, a la capacidad del sujeto responsable, al grado de la culpa, al contenido del deber de indemnizar, a las cláusulas de regulación, al diferente plazo de prescripción, a la competencia judicial, al caso de pluralidad de deudores o de agentes del daño, etc.

c) En cuanto al origen, la culpa extracontractual se diferencia de la contractual en que aquélla presupone un daño con independencia de cualquier relación jurídica antecedente entre las partes, fuera (en el sentido de distinta) del deber genérico y común a todos los hombres del alterum non laedere. Mientras que la segunda presupone una relación preexistente, que ordinariamente es un contrato pero que puede ser también cualquier otra relación jurídica que conceda un medio específico de resarcimiento.

d) No se opone a la diferenciación el que existan puntos de coincidencia, por cuanto, conforme al principio general de que quien causa daño lo debe indemnizar, lo mismo si se produce por incumplimiento de una obligación preestablecida que cuando proviene de culpa o negligencia no referidas a vínculo antecedente, siempre queda constituido el dañador en sujeto de una obligación que responde a un principo común de Derecho y a la misma finalidad reparadora. Finalidad reparadora que da lugar a unas notas comunes entre ambas clases de culpa: la producción de un daño, la atribuibilidad del mismo a un sujeto y el deber de éste de resarcir.

e) De los puntos de coincidencia y notas comunes se sigue también que la tajante separación originaria se atenúe en su aproximación a la común finalidad reparadora, mediante la aplicación indistinta de preceptos que pueden reputarse, con matizaciones, preceptos comunes por la necesidad de llenar las lagunas del Código.

f) Para que la responsabilidad contractual opere con exclusión de la extracontractual no es bastante que haya un contrato (o una preexistente relación de otra naturaleza) entre las partes, sino que se requiere para ello que la realización del hecho dañoso acontezca den- 
tro de la rigurosa órbita de lo pactado y como preciso desarrollo del contenido negocial, pues si se trata de negligencia extraña a lo que constituye propiamente materia del contrato, desplegará sus efectos propios la responsabilidad aquiliana.

La responsabilidad contractual «pura» se da sólo cuando el hecho se presenta como infracción de una de las obligaciones pactadas, de tal suerte que determinar el incumplimiento de la obligación depende íntegramente de la misma, siendo inimaginable su encuadramiento dentro del general deber de no dañar a otro.

g) Puede, por esto, darse la concurrencia de ambas clases de responsabilidades en yuxtaposición, que no desaparece sino cuando el acto causante se presenta con entera abstracción de la obligación preexistente: caso en el que la responsabilidad operaría con las mismas extensión e intensidad aunque aquella relación no hubiera existido nunca (supuesto de responsabilidad aquiliana pura), presentándose como violación —únicamente- del deber general de no dañar a nadie.

h) Si la separación de los dos regímenes es obligada, e inconcebible la coexistencia en los casos de la «responsabilidad contractual pura» y de la «responsabilidad aquiliana pura», no puede predicarse igual tratamiento en el caso (constitutivo de un tertium genus) en que el hecho dañoso es, inescindiblemente, incumplimiento de un deber contractual y a la vez violación, inseparable de aquél, del deber general de no causar daño a otra.

El hecho de que haya una relación preexistente, con su correspondiente régimen jurídico, no es bastante para eliminar la responsabilidad aquiliana presente a través de todos sus elementos definidores y operante, en yuxtaposición con aquélla, aunque en ámbitos diferentes. Pudiendo también entenderse, desde otra óptica, que detrás de los deberes contractuales - cuya infracción lleva consigo una responsabilidad de la especie llamada contractual - subsiste como fondo la extracontractual, completando a la primera e integrando los elementos conducentes a un pleno y satisfactorio resarcimiento, sin otro límite que la indemnidad del patrimonio económico o evitación del enriquecimiento.

\section{Algunos extremos que revelan la fragilidad de la distinción entre responsabilidad contractual y extracontractual}

Muchos son los aspectos en que se manifiesta la fragilidad de la distinción. La lectura de la doctrina europea (incluido el ámbito del common law) pone de relieve lo mucho que atormenta a los autores el deslin- 
de entre una y otra formas de responsabilidad y lo mucho que la propia jurisprudencia se resiente de una distinción cuyo fundamento es con frecuencia tan evanescente.

1. Destaca, cómo no, el problema de la delimitación misma de lo que deba entenderse por «contenido contractual».

No me voy a extender demasiado en la observación de que el contenido de un contrato (derechos y obligaciones que engendra para las partes) no puede circunscribirse, en modo alguno, a lo que ellas han convenido de forma expresa. Los efectos del contrato deben «integrarse» mediante el recurso a criterios muy variados, de los que en Derecho español son ejemplo la buena fe, el uso y la ley (artículo 1.258). Y esto, como dice nuestro Código, «según la naturaleza» de cada contrato.

Según creo, en nuestro Derecho ha sido el Tribunal Supremo el que - casi siempre con la mejor intención, esto es, en busca de soluciones justas - ha complicado el problema. Que, como dice el Tribunal, un daño sea contractual cuando acontece «dentro de la rigurosa órbita de lo pactado», «como preciso desarrollo del contenido negocial», dentro de lo que «constituye propiamente materia del contrato» y sea, por tanto, «infracción de una de las obligaciones pactadas», constituye una forma de delimitación que puede llevar, y ha llevado de hecho, a mi juicio, a conclusiones técnicamente dudosas.

Podría opinarse que no ha hecho bien el Tribunal Supremo cuando, tomando como base la responsabilidad extracontractual, y otorgando por tanto a la contractual un carácter puramente residual o definible por exclusión, no ha optado por entender que es contractual toda responsabilidad derivada de acontecimientos ocurridos en el marco de la relación de aquel nombre, excluidos desde luego aquellos que a todas luces no guardan relación alguna con ella.

Esa relación no existe, por citar casos extremos, cuando el arrendador atropella al arrendatario con su automóvil. O en la hipótesis de quien, habiendo sido contratado para realizar en una casa ciertas reparaciones, causa daños en el inmueble con motivo de la celebración de una fiesta sin autorización del dueño. O incluso el supuesto en el que la cosa vendida acarrea la muerte del comprador. En este último sentido, obsérvese la calificación implícita contenida en el artículo 5 de la Convención de las Naciones Unidas sobre los contratos de compraventa internacional de mercaderías (de Viena, 11 de abril de 1980, a la que se adhirió España por instrumento de 17 de julio de 1990), cuando dice que esa Convención no se aplicará a la responsabilidad del vendedor por la muerte o las lesiones corporales causadas a una persona por las mercaderías.

Pero, por otro lado, puede sostenerse —en defensa del criterio del Tribunal Supremo- el argumento de que con él se pone coto a las (en mu- 
chos casos insuperables) dificultades que entraña la determinación de hasta dónde llegan las denominadas «obligaciones de seguridad», esto es, aquellas que los tribunales se empeñan a veces en incluir en el contrato.

Basta recordar casos como los que, por particularmente reveladores de la irracionalidad de la diversidad de regímenes, se suelen citar por la doctrina, algunos de los cuales he mencionado antes. En el de «la botella que se explota» hace falta una gran dosis de imaginación para incluir en el contrato celebrado por el cliente y el supermercado la obligación del titular de este último de que las botellas no estallen. Al igual que es gran ficción, a mi juicio, entender que forma parte de las obligaciones contractuales del dueño del hotel la de que en el suelo de su vestíbulo no haya objetos aptos para producir resbalones. Del mismo modo que es ir muy lejos la inclusión, en el contrato de transporte ferroviario, de la obligación de que en el andén no ocurran percances a los viajeros.

Sabido es que un gran sector de la doctrina se muestra particularmente reacio a la extensión de estos «deberes de seguridad» (en Francia, Carbonnier y Huet).

En todo caso, la fórmula de diferenciación sentada por nuestro Tribunal Supremo convierte la tarea del intérprete en un innecesario desafío a su imaginación o, en otras palabras, en un aleatorio recurso a la ficción, como suele decirse en la doctrina inglesa. Sin perjuicio de que, en línea digna de elogio, la propia jurisprudencia haya adoptado fórmulas (procesales) de alivio o atenuación de las consecuencias extremas a que podría conducir la dualidad de regímenes.

Como antes he apuntado, no faltan casos en que las decisiones jurisprudenciales vienen inspiradas por un loable objetivo de proteger a la víctima, aunque a veces sea - a mi juicio - a costa de forzar los argumentos sin quizá necesidad de hacerlo.

Es caso particularmente significativo el de la sentencia de 10 de junio de 1991. El demandante, como consecuencia de la caída de un cable de arrastre en un telesquí, sufrió graves daños. Repárese en que se trata de un caso que casi coincide con otro de la jurisprudencia italiana, muy mencionado por la doctrina de aquel país.

La sociedad propietaria de la explotación tenía concertada una póliza que se denominaba «de seguro de responsabilidad civil general»; garantizaba «el pago de las indemnizaciones pecuniarias que, con arreglo a los artículos 1.902 y siguientes del Código civil, se viera obligada a satisfacer la entidad contratante por la responsabilidad civil extracontractual que pudiera serle imputada por los daños directos ocasionados a terceros, en sus personas o bienes, con motivo de la explotación y propiedad de las instalaciones» que al efecto se describían en el propio contrato. Repárese en que los términos de la póliza, que hemos transcrito literalmente, cir- 
cunscribían su cobertura, de forma particularmente precisa, al ámbito de la responsabilidad extracontractual.

Demandadas la sociedad propietaria de las instalaciones y la aseguradora, el Juzgado de Primera Instancia estimó parcialmente la demanda y condenó solidariamente a las dos demandadas. La Audiencia estimó la apelación de la compañía de seguros, a la que absolvió.

El Tribunal Supremo desestimó el recurso de casación de la empresa titular de la explotación pero en cambio declaró haber lugar al del demandante, confirmando en definitiva la sentencia del Juzgado.

Se observa en el razonamiento de la Sala el objetivo de llegar a una calificación (responsabilidad extracontractual) que permitiera condenar también a la compañía aseguradora demandada. Y para ello el Tribunal hace, a mi juicio, una prestidigitación dialéctica notable. Partiendo de lo que viene siendo doctrina jurisprudencial al respecto - la que antes he citado- dice el Supremo que la culpa imputada en el caso no nace de un defectuoso cumplimiento por parte de la propietaria de las instalaciones de esquí de las obligaciones originadas en el contrato de transporte concertado con el perjudicado, sino que se trata de un accidente sobrevenido por un funcionamiento defectuoso de las instalaciones, que motivó el descarrilamiento del cable y su caída por falta de las medidas de seguridad adecuadas para evitar daños a los usuarios de ese medio de transporte. Concluyendo el Tribunal que de todo lo anterior se desprende, no obstante la existencia de una relación contractual, que el hecho causante del daño no puede incardinarse como producido dentro de la órbita de esa relación y como desarrollo de su contenido negocial; en consecuencia, entra en juego el artículo 1.902, definidor de la responsabilidad extracontractual.

No me parece muy defendible la tesis de que proporcionar seguridad al cliente en el transporte no sea una de las obligaciones naturales del contrato de este nombre. Dicho de otro modo, el porteador se obliga a transportar y a hacerlo bien, esto es, de suerte que el viajero no sufra daños como consecuencia de defectos del propio sistema de transporte.

De otro lado, no creo que fueran obstáculo insuperable para condenar a la aseguradora los términos en que la póliza de seguro estaba redactada. Por el contrario, la expresa alusión en ella a «daños ocasionados a terceros con motivo de la explotación» habría permitido, a mi entender, que el Tribunal hubiese acudido al razonamiento, mucho menos forzado que el que utilizó, de que la letra de la póliza no era elemento bastante para negar al contrato de seguro un ámbito o radio de acción suficientes para ampliar la cobertura a los daños contractuales.

2. Otra expresión de la relatividad de la distinción que nos ocupa, o al menos de la necesidad de superarla cuando se trata de satisfacer adecuadamente determinados intereses, es la constituida por la llamada responsabilidad por productos defectuosos $o$ «del fabricante».

No debe olvidarse que en este terreno fue en el que, primero en Estados Unidos y luego en Inglaterra, se arbitraron por la jurisprudencia so- 
luciones encaminadas a una mayor protección de los consumidores. Aparentemente encorsetados los juristas por ciertos dogmas clásicos, como el de la privity of contract (el principio de relatividad de los contratos, en el Derecho continental europeo), diversas formulaciones más o menos ingeniosas (pero un tanto forzadas, como la del collateral contract o la de la extended vertical privity) condujeron a resoluciones judiciales por cuya virtud era condenado el fabricante aunque no hubiese mantenido relación contractual con el cliente, consumidor o destinatario final. Se trataba de poder imputar responsabilidad tanto a los fabricantes como a todos los participantes en las operaciones ulteriores de venta, incluyendo a los intermediarios intervinientes en el proceso de distribución.

Se recordará que la «falacia» de la privity of contract fue rechazada en Inglaterra en 1932 en el famoso caso Donoghue v. Stevenson (en una botella de cerveza se encontraron los restos descompuestos de un caracol). Se admitió que la demandante pudiese reclamar al fabricante de la cerveza en base al tort of negligence por daño personal y shock, aunque aquélla no había contratado con éste .

Como se sabe, el desenlace a que se ha llegado consiste en definitiva en hacer tabla rasa de la distinción entre ambas clases de responsabilidad, de suerte que lo que pasa a primer término es el derecho del consumidor a ser indemnizado, sin que juegue para nada (salvo matices) la circunstancia de que la compra se haya realizado al fabricante mismo o en el último eslabón de la cadena de distribución (en la doctrina española, Rojo Fernández-Río y Bercovitz, R.).

Así ocurrió ya en la Ley general para la defensa de consumidores y usuarios de 19 de julio de 1984, cuyos artículos 25 a 28 toman como punto de referencia el daño sufrido por el consumo de bienes o la utilización de productos o servicios, que se imputa indistintamente a quienes producen, importan, suministran o facilitan aquellos productos o servicios, sin particularidad alguna basada en la naturaleza de la relación entre responsable y víctima. Sólo el artículo 29 introduce un cierto factor de confusión al decir que el consumidor o usuario tiene derecho a una compensación, sobre la cuantía de la indemnización, «por los daños contractuales y extracontractuales», durante el tiempo que transcurra desde la declaración judicial de la responsabilidad hasta su pago efectivo.

La misma línea sigue la directiva de la Comunidad Económica Europea de 25 de julio de 1985 sobre responsabilidad por productos defectuosos. Sin que a mi juicio sea reparo a ese «desvanecimiento del carácter de la responsabilidad» el hecho de que el artículo 13 haga expresa reserva de «los derechos de que la víctima de un daño pueda valerse a título de Derecho de responsabilidad contractual o extracontractual», puesto que de lo 
que esta norma trata es (en virtud del principio pro consumatore) de asegurar al perjudicado la posible utilización de otros instrumentos adicionales distintos de la propia directiva.

A este criterio se ajusta, como no podía menos de ser, nuestro Proyecto de Ley sobre responsabilidad por los daños causados por productos defectuosos, que responde a la necesaria adaptación del Derecho español a la directiva comunitaria.

3. Un terreno en el que la distinción ha creado tan considerables dificultades a la jurisprudencia que en ocasiones ha llegado a prescindir de ella es el de la responsabilidad profesional (cuando se trata de obligación de medios, no de resultado), sobre todo el de responsabilidad de los médicos.

Aunque de ordinario la relación entre el paciente y el médico es de naturaleza contractual (excluidos los casos infrecuentes de asistencia al enfermo inconsciente o similares), y por mucho que se haya intentado ampliar en este caso los llamados «deberes de garantía» o «deberes de seguridad» para extender el ámbito del contrato, los tribunales españoles acuden con frecuencia a criterios propios de la responsabilidad extracontractual, quizá como consecuencia de que los demandantes orientan sus demandas por ese camino; y con el propósito, por tanto, de no frustrar una reclamación por motivos formales. Lo cierto es que no es raro que el Tribunal Supremo funde sus pronunciamientos en el artículo 1.902 del Código civil, habiendo llegado a decir alguna sentencia que en la responsabilidad civil del médico «concurren la responsabilidad contractual y la extracontractual».

1. Motivo de especial discusión es el caso de servicios profesionales prestados a través de entidades «interpuestas». Por ejemplo, servicios profesionales del abogado de un sindicato, o del médico de una compañía de seguros o de la Administración pública sanitaria. Sobre este extremo trato en una ponencia elaborada para un Congreso que se celebrará en Granada dentro de poco. La cuestión es en este punto particularmente delicada, en atención a que cuando se trata de una relación directa del médico con el paciente los tribunales siguen (con matices) el criterio clásico de la culpa, sin siquiera adoptar la inversión de la carga de la prueba. Mientras que cuando se trata de asistencia médica prestada por la Seguridad Social, por ejemplo, se recurre a una casi responsabilidad objetiva. Pero a mi juicio puede haber un desenfoque del problema, en el sentido de que cuando se condena al centro sanitario o a la institución de la que depende suele ser, en el fondo, por razón de «deficiencias asistenciales» propias del establecimiento como conjunto (esto es, por culpa del mismo), más que por deficiente actuación del médico; aunque no faltan casos en que esto último también se afirma o se insinúa. La responsabilidad del 
médico, propiamente dicha, creo que debe tratarse con el mismo criterio, tanto si su relación es directa con el cliente como si interviene una institución de Seguridad Social, según defiende una reciente sentencia de la Audiencia Provincial de Cantabria.

2. El carácter «fronterizo» de muchos casos de responsabilidad profesional se manifiesta en Derecho comparado; por ejemplo, cuando se trata de daños causados a un tercero distinto del cliente. Citando un caso, aquel en que a un abogado se le encarga la redacción de un testamento estableciendo un legado; el legado es inválido por culpa del abogado y el «tercero» lo pierde. Según el Derecho inglés, se adopta el criterio de tort, mientras que en Alemania se entiende que el contrato entre el abogado y el cliente es de los que producen «efectos protectores» para el previsto legatario (Zweigert y Kötz). Estos autores plantean también la cuestión en el caso de la información que se da y que luego resulta ser falsa. Cabe distinguir entre el daño causado a la persona a la que se transmite esta información y el que se produce en el tercero que confía en la información y se ve perjudicado por ello. Guarda mucha relación con este planteamiento la sentencia de nuestro Tribunal Supremo de 11 de junio de 1988, que consideró que en una misma conducta pueden concurrir responsabilidad contractual y extracontractual a la vez (se trataba del error en que había incurrido un notario, proyectado en los clientes del mismo y en terceros no concurrentes al acto de otorgamiento del documento público).

3. Que este problema no es privativo del Derecho español lo acredita el que haya sido puesto de relieve con particular énfasis en el reciente Coloquio sobre «la responsabilidad de los prestatarios de servicios» celebrado en Lausana los días 1 a 3 del pasado mes de setiembre.

Las ponencias correspondientes a Francia (Huet), Estados Unidos (Fleming), Alemania (Giessen) y Austria (Posch), por ejemplo, advierten de las dificultades que entraña la clásica dualidad de responsabilidades y, a la vez, de su superación — en buena medida - por la jurisprudencia de los respectivos países. La ponencia correspondiente a Inglaterra (Weir) señala cómo su ordenamiento cuenta con dos principales regímenes de responsabilidad, basado uno en las rules of contract y el otro en las rules of tort. La «pureza» de la primera de esas modalidades se advierte en el recurso a la idea (en definitiva, una ficción) del implied collateral contract, así como en las reticencias por parte de la doctrina sobre el juego estricto de la privity of contract. E interesa advertir cómo el autor nos dice que, aunque las obligaciones derivadas de cada uno de esos regímenes difieren un tanto en sus incidentes o intensidad, el common law no ha puesto ninguna objeción para su concurrencia en el sentido de permitir al demandante invocar uno u otro a su elección

El mismo «desvanecimiento» de la distinción se produce en otros casos en que el elemento de referencia que adopta la ley para establecer un tipo de responsabilidad es el de la actividad en cuyo desarrollo se produce el daño. 
Es el caso de las regulaciones legales que en algunos países tiene el «fenómeno» (no necesariamente el contrato) del transporte. O el de la actividad bancaria (Garofalo).

4. La jurisprudencia ha llevado a cabo también una considerable mitigación de los rigores de una línea fronteriza tajante en el caso de la responsabilidad por ruina de la obra del artículo 1.591. En él se consagra la llamada responsabilidad decenal de arquitectos y contratistas.

Aunque este precepto se inserta dentro de la reglamentación del arrendamiento de obra y es opinión fundada la que entiende que su objetivo originario fue el de resolver un problema de cumplimiento del contrato, que es ajeno a los posibles terceros perjudicados, la jurisprudencia ha ampliado el ámbito del precepto y con ello el catálogo de legitimados activamente.

De suerte que, por ejemplo, declara el Tribunal Supremo constantemente que el adquirente posee la misma acción que el dueño o comitente contra los responsables de la ruina, entendiendo que se trata de una acción protectora de la propiedad que se transmite junto con ésta. Del mismo modo, se amplía la legitimación pasiva por cuanto se admite que la demanda se entable contra el promotor, incluso cuando éste no ha sido además contratista.

En una palabra, se desvirtúan los rasgos «contractuales» de la responsabilidad y las soluciones jurisprudenciales hacen, en la práctica, que sean casi académicas las discusiones doctrinales sobre el carácter contractual, extracontractual, o para algunos legal, de la responsabilidad que esta norma establece. Discusión que, por ejemplo, nada tendría de estéril en lo que se refiere al plazo de prescripción de la acción (a partir del «plazo de garantía» de diez años), como tampoco lo tendría en relación con el párrafo segundo del artículo, que alude a la responsabilidad (ya no decenal) cuando la causa de la ruina fuese la falta del contratista «a las condiciones del contrato»; palabras estas últimas que parecen encerrar - a sensu contrario - la contemplación de unas hipótesis extrañas a «la órbita de lo pactado».

5. No menos reveladora de la imprecisión de la línea de separación de ambos regímenes de responsabilidad (o mejor dicho, de los supuestos que caen bajo uno y otro) es el caso de la responsabilidad precontractual o culpa in contrahendo. Es expresión del daño que en la formación de un contrato se produce a una de las partes a causa de la conducta de la otra; lo que podría extenderse al caso de daño cometido después de la expiración y cumplimiento del contrato. Y lo que de hecho, además, la jurisprudencia española ha trasladado al supuesto de quien rompe injustificadamente los tratos preliminares, violando deberes de lealtad y confianza de los que la otra parte era merecedora. 
Otro tanto sucede con las llamadas «relaciones contractuales creadas por virtud del contacto social», dentro de la categoría doctrinal que conocemos por «relaciones contractuales de hecho».

En estos casos no existen argumentos incontestables (al menos así lo acredita la división de la doctrina) para formular de forma tajante una calificación. Y estas discrepancias han trascendido al ámbito jurisprudencial, en el que las soluciones entre unos países y otros no son siempre coincidentes.

Desde el punto de vista técnico, el «escepticismo» sobre la dualidad de responsabilidades comienza en el momento mismo en que el papel de la voluntad (clave para la contractual) se reduce o desvanece.

1. En relación con los casos en que una de las partes de una negociación deja de dar a la otra información que es de vital importancia para esta última (a efectos de contratar), o cuando le suministra esa información sin el debido cuidado, el recurso a la culpa in contrahendo es, por ejemplo en Alemania, decisivo para evitar los inconvenientes del Derecho de daños y del Derecho contractual (Giesen).

Sobre las obligaciones «contractuales» resultantes de negociaciones frustradas y sobre la llamada precontractual «contractual» obligation, como expresión de la dificultad de hablar de tort o de contract, escribió Mehren en International Encyclopedia of Comparative Law.

2. La «incierta calificación» de la naturaleza jurídica de la responsabilidad precontractual (en el sentido más amplio de esta expresión) es motivo de discusión y de manifiestas discrepancias en la doctrina de Derecho internacional privado. También en ese terreno se precisa la «calificación» de que venimos hablando, esto es, la de contractual o la de extracontractual, a fin de subsumir el caso en la norma de conflicto que corresponda; a efectos sobre todo de determinación de la ley aplicable. Todo ello, sobre la base de que la opinión dominante entiende que esa «cuestión de calificación» debe resolverse por las concepciones de la lex fori. Sobre esto ha escrito recientemente entre nosotros Alvárez González.

6. Así mismo, la distinción se desvanece en materia de derechos de la personalidad cuando - como ocurre hoy en muchos países- la sanción de los actos de atentado a los mismos toma como punto de referencia el bien jurídico protegido (salud, integridad, honor, etc.), no el marco en que el atentado se produce. En este caso de régimen específico de responsabilidad en función del bien lesionado creo que no tiene relevancia la existencia o inexistencia de una relación contractual previa, salvo que la norma establezca otra cosa.

Y si no es así, la concurrencia de perspectivas (contractual y extracontractual) parece evidente (Visintini, refiriéndose al «derecho a la salud». En la doctrina suiza, Tercier). 
7. También contribuye a difuminar la frontera entre culpa contractual y extracontractual la posibilidad de que el incumplimiento doloso de la obligación merezca el mismo trato (a efectos de determinación del daño indemnizable) que si de un caso de culpa extracontractual se tratara. Así podría entenderse en el Derecho español, mediante la aplicación de criterios de relación de causalidad (en rigor, de imputación objetiva) semejantes en ambas hipótesis. La previsión del párrafo segundo del artículo 1.107 para el caso de deudor que incumple por dolo sería trasladable a los daños extracontractuales; pero debidamente interpretada - para ambos casos- la exagerada fórmula del precepto («todos los daños que conocidamente se deriven de la falta de cumplimiento»).

Creo que aceptarían esta intepretación incluso los autores que más insisten en el criterio de la previsibilidad como rasgo propio de la responsabilidad contractual. Y no tanto porque el incumplimiento doloso sea equiparable al cuasidelito español (o al délit francés), sino porque la «finalidad protectora» de la norma que consagra la responsabilidad dejaría de tener sentido en quien incumple dolosamente.

Téngase presente, en este punto, que la jurisprudencia francesa (aunque se trata de criterio muy discutido) ha excluido de la regla del non-cu$m u l$ - a la que luego me referiré- el caso de incumplimiento por dolo.

8. En este orden de cosas, tampoco puede dejar de mencionarse (al igual que en alguna doctrina extranjera) el elemento de distorsión de la dualidad que ocasiona la llamada «tutela aquiliana del crédito», esto es, el caso en que la lesión el derecho de crédito se produce por obra de un tercero. Se puede dar así la concurrencia de ambos tipos de responsabilidades en un mismo caso, originando situaciones llenas de problemas (y en algún caso pintorescas) que los autores y la jurisprudencia han puesto de relieve.

Como es sabido, subyace en esta cuestión un problema dogmático derivado del carácter relativo que tradicionalmente se atribuye a los derechos de crédito. En principio se diría que éstos no dan lugar a ningún deber a cargo de terceros, pero se señala también que existe un deber de respeto del derecho de crédito cuya vulneración implica una modalidad de responsabilidad extracontractual, según la doctrina dominante.

9. Por fin, y en atención a que una de las consecuencias más notables de la distinción consiste en el alcance del deber de indemnizar, esto es, en la cuantía de la reparación, permítaseme la opinión de que contribuyen a reducir o desvanecer esa diferencia todos los criterios que en la actualidad desvirtúan la pureza de los principios clásicos en la materia. 
a) Me refiero en primer lugar al escaso relieve que en la jurisprudencia de algunos países tiene, de hecho, la distinción entre daños previsibles e imprevisibles, a efectos de imputar sólo los primeros, no los segundos, al incumplimiento de las obligaciones contractuales que no sea producto de dolo.

Este escaso relieve puede consistir, como ocurre por ejemplo en Francia, en la «reticencia» (en palabras dc Viney) que la jurisprudencia de aquel país ha manifestado hacia el artículo 1.150 del Code, precepto en el que como es sabido se excluyen en principio los daños imprevisibles en materia contractual; salvo en caso de dolo, en el que la reparación de dichos daños se admite al igual que ocurre en la responsabilidad extracontractual.

En Italia, alguna opinión (Visintini) sugiere en este punto una aproximación entre el régimen contractual y el extracontractual, siquiera sea con una original interpretación del artículo 1.255 de su Código civil; en concreto, de las palabras «tiempo en el que ha surgido la obligación», en contraposición a la expresión que utilizaba el Código de 1865 («tiempo del contrato»).

Por lo que a España se refiere, la doctrina pone de manifiesto que nuestra jurisprudencia ha desconocido el párrafo segundo del artículo 1.107 («todos los daños que conocidamente se deriven de la falta de cumplimiento»), operando en este extremo con un criterio de unificación similar al vigente en el common law o en la Convención internacional sobre compraventa de mercaderías, de 1980. Criterio que algún autor (Carrasco Perera) elogia, aunque no es opinión unánime. De hecho, lo cierto es que nuestro Tribunal Supremo no suele hacer explícitos razonamientos de deslinde entre lo que es previsible e imprevisible.

b) En segundo término, procede citar la tendencia doctrinal que sugiere la adopción de reglas de limitación en la determinación del montante de las indemnizaciones. Es preciso acudir de nuevo a Viney cuando dice que le parece necesario tomar conciencia del hecho de que las sumas que pueden dedicarse, en un momento dado y en un país dado, a la indemnización de las víctimas de daños no deberían exceder de un cierto límite, más allá del cual el sistema puede poner en grave peligro el dinamismo económico.

Es digno de señalarse que la autora francesa considera importante establecer un orden de urgencia entre los diferentes tipos de daños, dando prioridad a los que amenazan los intereses más esenciales de los individuos o de los grupos. Por lo que se muestra dispuesta a admitir que la indemnización de los daños corporales se considere prioritaria y que la de los daños económicos sea más completa que la de los puramente morales. Y expresa su postura favorable a una «tarificación» que, hecha con flexi- 
bilidad, sobre la base de estudios objetivos y con la mira puesta en la protección más generosa posible de las víctimas, llenaría una de las lagunas más graves que la autora dice encontrar en el sistema actual de responsabilidad civil.

c) Ha de tenerse presente, por otro lado, que esta idea de limitación de las indemnizaciones por vía de adaptación al caso concreto ha encontrado reflejo ya en algún ordenamiento positivo. No se trata sólo de reglas específicas, como las que en algunos países conducen al establecimiento de «techos de indemnización» en casos concretos (por ejemplo, en los daños medioambientales), sino que me refiero a reglas de carácter general como se conocen ya en algunos ordenamientos.

Una muy significativa es la del artículo 44, párrafo segundo, del Código suizo de las obligaciones, al establecer que «cuando el perjuicio no ha sido causado ni intencionadamente ni como consecuencia de una grave negligencia o imprudencia, y cuando su reparación llevaría al deudor a la ruina, el juez puede equitativamente reducir los daños y perjuicios». Por otro lado, el artículo 99, párrafo segundo, del mismo cuerpo legal dispone que la responsabilidad se aprecia con menos rigor cuando el negocio no está destinado a procurar una ventaja al deudor. La jurisprudencia suiza aplica esta regla por analogía a la responsabilidad extracontractual. Por su parte, el artículo 43, párrafo primero, del mismo Código suizo justifica la reducción de la indemnización cuando la producción o agravación del daño ha sido favorecida en medida importante por circunstancias fortuitas que no tienen relación con el comportamiento del autor o de la víctima. En definitiva, estos preceptos dan al juez una libertad de apreciación que - como señala la doctrina de aquel país - casi no se da en todo el Derecho de obligaciones.

Podría citarse también el caso del artículo 109 del Libro 6 del Código civil holandés, que atribuye a los tribunales el poder de reducir la obligación legal de reparar el daño en los casos en que la concesión de una reparación completa «pudiese conducir a resultados claramente inaceptables». Entre los factores que pueden tenerse en cuenta están la naturaleza de la responsabilidad (por ejemplo, riesgo versus culpa), la relación jurídica entre las partes y su respectiva capacidad financiera. No existe posibilidad de reducir los daños, sin embargo, si la responsabilidad del deudor está o debería haber estado cubierta por un seguro.

d) En la misma línea de aproximación de ambos regímenes puede mencionarse, en Inglaterra por ejemplo, la reciente admisión del pure economic loss en el caso de tort(negligence).

Sobre los problemas de ese concepto indemnizatorio en Derecho comparado, y su juego en tort y en contract, ha escrito recientemente Banakas. 
e) También se ha experimentado una sensible relajación de la distinción que nos ocupa en los casos de concurrencia de culpa de la víctima, hipótesis en la que en la mayoría de los países la cuantía de los daños se reduce con iguales criterios en sede contractual que extracontractual (Weir, Complex liabilities).

f) De otro lado, parece innegable que los jueces, con frecuencia, se apartan de los esquemas dogmáticos en materia de alcance del deber de responder y adoptan un criterio casuístico en el que juega indudable papel la valoración de las concretas circunstancias concurrentes, entre ellas el grado de gravedad de la culpa del agente.

1. Sin entrar en detalles impropios de este lugar, sí conviene señalar que las fórmulas legales y jurisprudenciales de limitación o mitigación de los daños son en nuestros días objeto de atención muy especial por parte de la doctrina, cosa infrecuente hace 20 años.

Es significativo que en el tomo correspondiente a Contracts in general de la International Encyclopedia of Comparative Law, y dentro del capítulo relativo al incumplimiento del contrato, el autor del mismo (Von Mehren) dedique una considerable extensión (páginas 55 a 90) al apartado de «Métodos de limitación de los daños». Por ejemplo, allí se citan los siguientes aspectos: relevancia del grado de culpa sobre la extensión de la responsabilidad; previsibilidad, su objeto y criterios para su valoración; relación de causalidad; discrecionalidad judicial; mitigación o reducción (por ejemplo, en relación con una pérdida que el demandante debía haber evitado, o con un beneficio que el demandante ha obtenido a causa del incumplimiento del demandado, o con la concurrencia de culpa de la víctima); la «certeza» del daño; limitaciones específicas (por ejemplo, el caso de daño a los sentimientos, o el relativo al tipo de interés en las obligaciones pecuniarias); etc.

En lo que se refiere a la responsabilidad extracontractual, también se plantean por la doctrina cuestiones en la misma línea. Tratando sobre Consequences of liability: Remedies, en la misma Enciclopedia, Stoll dedica un subcapítulo al tema Mitigation of damages and equitable liability. Desarrolla allí el autor las «soluciones típicas» que llevan consigo mitigación de la indemnización o excepción al principio de compensación completa. Una de ellas es la existencia de «límites rígidos» de reparación, otra la basada en la proporcionalidad entre la culpa y la responsabilidad y otra, en fin, la vía de reducción equitativa de los daños en casos excepcionales, bien en base a cláusulas de discrecionalidad judicial, bien por medio de «cláusulas reductoras» en ámbitos concretos.

2. Sobre todo en materia de reparación de daños que por naturaleza son de apreciación subjetiva, por ejemplo los llamados «daños personales», me parece evidente que los jueces hacen uso de la discrecionalidad propia del caso utilizando criterios de valoración que en nada se parecen a los esquemas o arquetipos que estamos acostumbrados a manejar en la 
teoría. En Francia, por ejemplo, algunos autores no ocultan su opinión de que a pesar de los continuos pronunciamientos dogmáticos en sentido contrario, los jueces valoran el grado de culpa a la hora de fijar la indemnización.

No cabe ignorar que en Francia, donde la reparación del daño imprevisible se admite en materia extracontractual, se excluye en principio en materia contractual (artículo 1.150), excepto en los casos de faute lourde. Pero con la observación de que esta diferencia de trato ha merecido los reparos de la doctrina y, por lo que se ve, encuentra poca acogida en los tribunales.

\section{Fórmulas legales o jurisprudenciales que mitigan los rigores de la dualidad de regímenes}

Expongo (sin propósito de exhaustividad, desde luego) algunos instrumentos que, bien por vía legal, bien por vía jurisprudencial, podrían contribuir a la eliminación o al alivio de las consecuencias más sangrantes de la dualidad de regímenes de responsabilidad.

\section{A) Unificación (relativa) de regímenes}

Una posibilidad es la constituida por un sistema que unifique ambos regímenes, en todos aquellos puntos en que la realidad de las cosas lo permita.

El punto de partida técnico de esta orientación consiste en la idea (compartida por no pocos autores) de que si la culpa es violación de una obligación preexistente, la naturaleza de la responsabilidad es siempre la misma, tanto se trate de la vulneración de una obligación nacida de un contrato, de una obligación legal, o de la obligación general de diligencia impuesta a todos los hombres. A lo que se añade la evidencia de que muchas de las diferencias entre ambos regímenes no responden a la «naturaleza de las cosas», es decir, son divergencias que se pueden eliminar sin causar distorsión en ninguno de los dos sistemas normativos, el contractual y el extracontractual.

Se invocan otras razones de carácter «conceptual», pero no hay espacio para mencionarlas en detalle. Sí se puede, en cambio, señalar que una de aquellas justificaciones es la de que si la razón de ser del particularismo de la responsabilidad contractual está en el origen mismo de la regla infringida (el acuerdo de voluntades), parece razonable entender que la contraposición entre norma contractual y norma legal tiene cada día menos sentido, visto que el contenido del contrato se ve, también cada día, más reglamentado por la ley; y escapa, de forma creciente, a la voluntad de las partes. 
Cuando hablamos de «unificación» es preciso distinguir entre aquellos esfuerzos encaminados a la unificación formal de los presupuestos de la obligación de indemnizar y los que se conforman con mantener la diversidad en la descripción de dichos presupuestos y reducen la unificación al régimen de indemnización en sentido estricto.

1. Sería ejemplo de lo primero el caso de uno de los proyectos actualmente en curso en Argentina.

De los dos que al parecer existen, uno es el de la comisión formada por los señores Belluscio y otros, de cuya actividad da cuenta Kemelmajer de Carlucci, en cuya información me baso.

En este proyecto, la solución gira en torno a un principio que podría denominarse «inexistencia de un derecho a dañar».

El artículo 549 dice: «La violación del deber de no dañar a otro genera la obligación de reparar el daño causado conforme a las disposiciones de este Código». No se distingue entre tipos de daño. La evidencia de que la relación contractual es algo distinto del daño extracontractual se salva, por ejemplo, usando la expresión dual de «el acreedor o la víctima», que se acomoda a las dos hipótesis.

A partir de esta idea de la «inexistencia de un derecho a dañar», los criterios de antijuridicidad, imputabilidad, factores de atribución, relación de causalidad y resarcimiento del daño son casi en su totalidad idénticos para ambos casos; o mejor dicho, únicos.

No obstante, sigue habiendo - esto es inevitable — reglas específicas (de pura delimitación o definición del supuesto de hecho) cuya razón de ser se acomoda a la fisonomía de algunos daños que por definición sólo pueden ser extracontractuales.

A pesar de esta «máxima unificación formal» que el proyecto argentino representa, no hay que olvidar además que el régimen de responsabilidad (como cosa distinta de los supuestos de responsabilidad) no ha podido ser objeto de unificación absoluta, como ocurre por ejemplo en lo que se refiere a mancomunidad o solidaridad en el caso de pluralidad de responsables o en lo que respecta a la responsabilidad de los padres, hipótesis esta última en la que los progenitores no responden de los daños derivados de los incumplimientos contractuales de sus hijos. Se trata, señala la autora antes citada, de «una nueva concesión que se ha debido hacer al dualismo».

2. Junto a esta fórmula (ya que no frente a ella) está la de algunos sistemas jurídicos en los que los supuestos de hecho (algo así como la 
descripción del tipo) se mantienen perfectamente diferenciados. De suerte que, como decíamos antes, la unificación se produce por vía de un régimen único de resarcimiento. Como es claro, entre una y otra fórmulas no hay ninguna diferencia, más que la puramente formal. De ahí que la argentina (basada en la genérica sanción de todo daño) me parezca en el fondo innecesaria.

Esta segunda vía de las dos que menciono encuentra manifestaciones como son la del Derecho suizo, la del Código civil portugués y la del holandés.

En Suiza, el daño y su reparación son tratados de manera uniforme. Igual ocurre en lo que se refiere a la relación de causalidad. Téngase presente que el artículo 99, párrafo tercero, del Código de las obligaciones dispone que «las reglas sobre la responsabilidad que deriva de actos ilícitos se aplican por analogía a los efectos de la culpa contractual». Sin embargo, existen diferencias; por ejemplo, en materia de plazo de prescripción (de un año en la responsabilidad extracontractual y de diez —en general- en la contractual), en lo que respecta a la responsabilidad por hecho de los auxiliares y en punto a la prueba de la culpa.

La «inclinación» unificadora en Derecho suizo se manifiesta, por ejemplo, incluso en el plano doctrinal. En efecto, aunque hay alguna opinión discrepante, la mayor parte de los autores entienden por responsabilidad civil la obligación, a cargo de una persona, de reparar los daños causados a otro. De tal forma que es usual subdividir el concepto de responsabilidad civil en los de daño contractual y daño extracontractual. Y no es infrecuente que las obras generales sobre responsabilidad civil comprendan tanto la responsabilidad civil propiamente dicha, que diríamos nosotros, como la «responsabilidad civil contractual», bien en términos generales, bien en lo que se refiere a la concreta disciplina de los diferentes contratos. De ahí que la teoría de la obligación consistente en indemnizar daños y perjuicios empareje a los que son consecuencia de un acto ilícito (artículos 41 y siguientes del Código de las obligaciones) y a los que derivan del incumplimiento de un compromiso contractual (artículos 97 y siguientes). Por ejemplo, en reciente obra de Merz. No ocurre así, sin embargo, en la obra de Deschenaux y Tercier.

Por lo que se refiere al Código civil portugués, siguiendo la fórmula clásica trata de las dos formas de responsabilidad en lugares diferentes y sitúa la contractual en el capítulo en que regula, al lado del cumplimiento, las formas y efectos del incumplimiento de las obligaciones (artículos 798 y siguientes). Con lo que, aunque no se recoja enteramente la doctrina tradicional de diversidad de régimen entre ambas modalidades, se reconoce que la contractual tiene aspectos específicos cuyo lugar propio se sitúa en el terreno del cumplimiento y del incumplimiento. 
Al contrario, la responsabilidad civil se configura como una de las fuentes de las obligaciones. Pero su regulación se encuentra sensiblemente reducida, puesto que se limita prácticamente a los presupuestos de la responsabilidad. Por el contrario, los efectos de esta responsabilidad extracontractual, en lo que respecta a la determinación de los daños indemnizables (problemas de nexo de causalidad), las formas de indemnización y el cálculo de su montante se reglamentan en el capítulo relativo a los diversos tipos de obligaciones; y en concreto dentro de la denominada obligación de indemnización, que comprende los aspectos comunes a uno y otro tipos de responsabilidad.

En este foro académico en que nos encontramos, es interesante, creo, hacer constar la opinión que Antunes Varela expresa acerca de la divergencia que puede existir entre la sistematización lógica del Código civil portugués y una mejor ordenación didáctica de las materias. Opina el autor que el desplazamiento de los aspectos comunes a las dos responsabilidades a un capítulo autónomo, que no se integra en ninguna de ellas, da como resultado que el estudio de una y otra, en el lugar que les corresponde dentro del plano metodológico de la exposición, quede forzosamente incompleto. Y tal vez haya una mayor ventaja en dar al estudioso una exposición de la responsabilidad contractual en el lugar destinado al contrato.

El nuevo Código civil holandés, por fin, constituye la más reciente expresión legislativa europea de la inquietud a que vengo refiriéndome.

En efecto, una de sus particularidades radica en el hecho de que la «obligación legal de indemnizar los daños» (artículos 95 a 110 del Libro 6) se aplica a todo caso, incluyendo por tanto la responsabilidad que deriva del incumplimiento de una obligación (contractual o de otro tipo), del acto ilícito y del enriquecimiento injusto. No se refiere el Código a los daños que son objeto de las previsiones contractuales, como los liquidated damages y el seguro.

Hablando del Código civil holandés, no puede dejar de mencionarse su singularidad en materia de fuentes de las obligaciones. Como es sabido, muchas veces se ha entroncado el problema de la dualidad de regímenes de responsabilidad con la discutida cuestión de las fuentes, que ha dado lugar a literatura tan abundante como en buena medida estéril, a mi juicio; de suerte que la referida dualidad de regímenes podría verse particularmente sujeta a críticas si se aceptase la posición «reduccionista» extrema según la cual, en definitiva, la ley es la única fuente.

Y en este sentido es curioso que el artículo 1 del Libro 6 diga que «las obligaciones no pueden nacer más que cuando así resulta de la ley». Se trata de una significativa forma de hablar, que responde al extendido criterio del Derecho holandés de que cualquier fuente de obligaciones tiene 
esta condición en virtud de la ley. Este principio legal (en el que creo encontrar algo así como un «principio de legalidad» del Derecho de obligaciones, similar —-salvadas las distancias - al nullum crimen sine lege del Derecho penal) no impide observar que, no obstante, sigue habiendo «fuentes» distintas de la ley. Aunque no existe una lista como ocurre en otros códigos, son fuentes de obligaciones el contrato y el acto ilícito; y junto a ellas, el legado, la gestión de negocios ajenos, el pago de lo indebido y el enriquecimiento injusto. El Título tercero de dicho Libro versa sobre «el acto ilícito», el cuarto sobre las «obligaciones que resultan de fuentes distintas del acto ilícito o el contrato» (por tanto, la palabra «fuentes» se encuentra en la rúbrica de un Título) y el quinto trata sobre «los contratos en general».

Volviendo a la unificación del régimen de indemnización a que nos hemos referido, aquélla se articula introduciendo en el Título primero del Libro 6 («de las obligaciones en general») una Sección 10 dedicada a «las obligaciones legales de reparación del daño». Sin ánimo de hacer una exposición completa, y dando a los artículos una denominación mía propia, los que contiene dicha Sección tratan sobre lo siguiente: el 95, definición legal del daño; 96, contenido del daño patrimonial; 97, atribución al juez de valoración discrecional; 98, extensión del deber de indemnizar o relación de causalidad; 99, daño que es consecuencia de varios acontecimientos; 100, compensatio lucri cum damno; 101, concurrencia de culpa del perjudicado; 102, daño causado por varias personas; 103, reparación del daño en dinero o en otra forma; 104, valoración de la ventaja obtenida por el autor del daño; 105, facultad del juez de diferir la evaluación del daño o anticiparlo; 106, reparación de perjuicio no patrimonial; 107, daños causados a terceros en el caso de lesión corporal o mental de la víctima propiamente dicha; 108 , indemnización por causa de muerte; 109, facultad judicial de reducir la obligación en el caso de consecuencias manifiestamente inaceptables; 110, limitación legal de la responsabilidad cuando concurre el seguro.

Pero ello no significa que la responsabilidad extracontractual haya perdido su autonomía en cuanto a sus presupuestos se refiere, dado que el Título tercero del Libro 6 tiene por objeto «el acto ilícito», como cosa diferente de las «obligaciones derivadas de fuentes distintas del acto ilícito o el contrato» (Título cuarto) y de las dimanantes del contrato (que en sus generalidades es objeto del Título 5). La Sección 1 del Título dedicado al acto ilícito contiene «disposiciones generales», la 2 se refiere a responsabilidad por hecho ajeno y por las cosas, la 3 trata de la responsabilidad por productos (por cierto, incorporando al Código civil los principios de la directiva comunitaria de 1985, en vez de haberse acudido a la fórmula de una ley especial), la 4 tiene por objeto la publicidad engañosa y la 5 reglamenta el régimen temporal de los derechos de repetición o reembolso. 
Dentro de esa reglamentación se contienen normas sobre el significado mismo de la ilicitud (162.2), la imputabilidad en sentido amplio (162.3), la finalidad protectora de la norma como criterio de imputación (163), la imputabilidad en el caso de menor de 14 años o de mayor de esa edad que causa el daño bajo los efectos de una incapacidad mental o física (164 y 165), el daño causado por el miembro indeterminado de un grupo (166), daños causados a través de publicaciones (167) y rechazo de la demanda encaminada a la prohibición de una conducta ilícita, por importantes intereses sociales (168).

En consecuencia, se observa de nuevo el carácter de «unificación relativa» a que antes me he referido. La estructura, e incluso el simple volumen físico de la reglamentación del acto ilícito como tal, no de su reparación, son por lo menos iguales que los de los códigos de la familia del francés, si no superiores.

Interesa señalar lo que el Código establece en materia de corresponsabilidad. El artículo 6 del Libro 6 opta por el criterio del cumplimiento pro parte, con la salvedad de que otra cosa venga dispuesta por la ley, por el uso o por un acto jurídico. Sin embargo, el artículo 102 declara la solidaridad como regla en el caso de que varias personas estén obligadas a reparar el mismo daño. Regla que parece dar entrada a la distinción doctrinal entre pluralidad de deudores a efectos del cumplimiento y pluralidad a efectos de la indemnización, contraste sólo imaginable en el caso de la responsabilidad contractual.

Por cierto, no sé si el artículo 98 del Libro 6 no permite sostener que el alcance del daño indemnizable puede ser distinto en el caso de culpa contractual que en el de la extracontractual. A este respecto, y partiendo del principio de que la obligación de indemnizar presupone que el incumplimiento o el acto ilícito es la causa del daño sufrido por el demandante, debe recordarse que desde los años 20 hasta los 70 los tribunales holandeses se adherían a la teoría de la causa adecuada: se exigía que el deudor hubiese podido razonablemente prever el daño (incluyendo su extensión) al tiempo de la conclusión del contrato. El mismo criterio se adoptaba en materia de responsabilidad extracontractual, en cuyo caso, desde luego, sólo el momento en que el daño se cometió podía ser decisivo. En los años 60, una nueva corriente doctrinal criticó el criterio de la previsibilidad, sosteniendo lo que en definitiva ha venido a decir el artículo 98. Este precepto establece que «la reparación no se extiende más que al daño cuya relación con el acontecimiento sobre el que se funda la responsabilidad del deudor es tal que, teniendo en cuenta también la "naturaleza de la responsabilidad" y del daño, puede ser imputado al deudor como una consecuencia de aquel acontecimiento». Me pregunto si la alusión a la «naturaleza de la responsabilidad» no puede dar cabida a criterios, como el de la previsibilidad, propios de lo que llamamos el daño contractual. 


\section{B) La vía procesal: modo de formular la pretensión}

Parece evidente que en aquellos ordenamientos en que subsiste (materialmente hablando) la dualidad de regímenes, el gran reparo práctico que suscita esa dualidad consiste en las diabólicas dificultades que a veces entraña la previa calificación que el demandante ha de hacer, con riesgo de que si se equivoca cuente únicamente, en el mejor de los casos, con la posibilidad de reproducir su reclamación por la vía que al principio descartó. Si esto es así, creo que en buena medida nos encontramos en presencia de un problema procesal fácilmente superable sin que por eso se vea afectada la rectitud del proceso ni dañada la posición del demandado. Y sin que tampoco sufra demasiado, en muchos casos, el interés efectivo del actor, materializado en la condena del demandado. Esa posibilidad existe si los tribunales, por así decirlo, eximen al demandante de tan desproporcionada carga y le permiten formular alternativamente su pretensión.

Los inconvenientes prácticos (a la hora de hacer efectivos los derechos a través del proceso) se han puesto particularmente de relieve en un país, como Francia, en el que juega en principio la regla de «la no acumulación» (el non-cumul) a que luego me referiré. Se advierte por los autores que la fórmula francesa es «elegante» (desde el punto de vista de la coherencia técnica), pero incluso el sector doctrinal que la apoya reconoce la realidad de que el demandante, en aquel país, debe especificar en qué artículos del Código basa su demanda y si lo hace erróneamente debe comenzar de nuevo. Por otro lado, el juez debe citar los artículos correctos en su sentencia, o si no ésta será anulada. Eso significa que en todos los casos de discutible concurrencia de reclamaciones, que son muy numerosas, debe determinarse si el acto enjuiciado se refería a una obligación contractual válida; y esta delicada determinación debe hacerse por ambas partes y por el juez de forma separada.

La cuestión se plantea (sin perjuicio de matices) en los siguientes términos: si a la víctima de un incumplimiento de contrato le está permitido o no beneficiarse de la calificación que prefiera y orientar su reclamación, por tanto, bien por vía del daño contractual, bien por el camino del daño extracontractual.

Weir describe estas posibilidades de forma muy gráfica: ¿Dispone el demandante de un billete adecuado para cualquiera de estos dos caminos, a efectos de ver satisfecha su pretensión? Partiendo de esta metáfora, el mismo autor da tres respuestas, diciendo que en Francia sólo tiene un billete para una determinada carretera, en Alemania dispone de dos billetes y en el área del common law debe dar uno de ellos a la puerta y a veces se le pregunta cuál debe ser. 
Lo que en todo caso se excluye es la posibilidad de que el demandante acuda a una acción («híbrida», dicen Weill y Terré), de naturaleza a la vez contractual y delictual, por cuya virtud el demandante escogería las reglas de la responsabilidad extracontractual o contractual que le fuesen más favorables, conjuntamente. Por eso es por lo que en la doctrina francesa se advierte que la palabra «cumul» no es la adecuada para lo que se entiende como tal. Se trata más bien de una elección, es decir, de una opción. Los citados autores plantean la verdadera cuestión de la forma siguiente: el acreedor que alega el incumplimiento culpable del contrato por parte de su contratante, ¿podrá invocar, a su elección, bien las reglas de la responsabilidad contractual, bien las de la extracontractual, si éstas o aquéllas le son favorables? ¿No se puede sostener que, incluso en relación con el acreedor, la culpa en que ha incurrido el deudor puede dar lugar a la aplicación del artículo 1.382, dado que este texto se refiere a «cualquier» culpa? O en fin, ¿acaba el terreno de la responsabilidad delictual donde comienza la contractual, al igual que, al revés, un hecho que no constituye violación de una obligación contractual por el deudor no puede dar lugar más que a la aplicación de la responsabilidad delictual?

En este punto, el examen del Derecho comparado advierte de la existencia de al menos dos regímenes posibles (Tunc, Viney y Weir):

a) Uno de ellos es el de Francia, cuya jurisprudencia se inclina hacia la regla del «non-cumul» aunque con algunas excepciones (pocas). Los tribunales franceses entienden que los artículos 1.382 y siguientes no son aplicables cuando se trata de incumplimiento de la obligación derivada de un contrato. Frente a la tesis de que las reglas de responsabilidad extracontractual son de orden público y constituyen un mínimum de protección que el contrato puede ampliar pero no reducir, la opinión favorable al «non-cumul» defiende que el problema debe resolverse no en el terreno de la presunta superioridad de uno de los dos sistemas sobre el otro, sino en sus respectivos campos de aplicación. Por otro lado, cuando las partes han acordado, por ejemplo, que no haya responsabilidad en tal o cual caso, permitir al acreedor la invocación de la responsabilidad delictual sería tanto como autorizarle a violar el contrato. En definitiva, se acude al argumento del respeto a la voluntad del legislador y también a la voluntad de las partes del contrato.

Por eso, si el demandante se coloca exclusivamente en el terreno de la responsabilidad delictual y el demandado opone la excepción consistente en la aplicabilidad de las reglas contractuales, el tribunal —si está de acuerdo con el criterio del demandado- desestima la demanda.

La jurisprudencia francesa declara que los jueces no pueden levantar de oficio la regla del «non-cumul», ni fundar su decisión sobre normas distintas de las alegadas por el demandante. 
Algunos autores manifiestan su deseo de que se superen estos criterios demasiado formalistas, de forma que el juez pueda llevar a cabo la sustitución (de normas) que el caso requiera. Por lo demás, no faltan autores que ante un caso como el planteado dicen que el juez, aun reconociendo la inadecuación de las reglas de responsabilidad delictual, puede colocar el litigio en su verdadero terreno y aplicar las normas sobre la responsabilidad contractual. No obstante, no parece que es ésta la solución dada por los tribunales franceses y no faltan autores que defienden el rigor de la regla clásica. Se invoca al efecto el argumento del «derecho de defensa».

Este último reparo ha sido sostenido por mí recientemente como consecuencia de algún pronunciamiento de nuestro Tribunal Supremo. Decía que por mucha que sea la flexibilidad de los tribunales en cuanto a la calificación de la acción por parte del actor, no por eso quedan solventadas algunas cuestiones de fondo.

En efecto, sería absurdo pensar que una doctrina jurisprudencial que admitiera la condena con fundamento en preceptos distintos de los invocados por el demandante constituyese «la solución» del problema en que nos encontramos. En esa hipótesis sería el tribunal el que decidiese sobre el «nombre» que atribuir a la responsabilidad del caso concreto, pero al hacerlo así el juzgador estaría planteando, inevitablemente, la cuestión relativa a la prescripción de la acción. Dado que ésta sólo opera a instancia de parte, la «conversión» llevada a cabo por el tribunal podía haber impedido al demandado invocar dicha excepción. Si no lo hizo como consecuencia de la forma en que el demandante formuló su demanda, el derecho de defensa quedaría conculcado.

Otro tanto puede ocurrir respecto a la competencia territorial del juzgado ante el que se formula la demanda. El tribunal que conoce puede tener que resolver — si el demandado lo plantea - sobre su propia competencia. Y cabe que el demandado no suscite esa cuestión precisamente por la forma en que el actor ha fundado su pretensión.

Estas observaciones que formulo mueven a plantear el desideratum de que los plazos de prescripción se unifiquen y se establezca una única regla de competencia judicial territorial, acaso en forma de alternativas a elección del demandante. Pero mientras eso no suceda, el riesgo que entraña la calificación sigue subsistiendo, incluso en el caso de fundamentación alternativa de la demanda.

$\mathrm{Si}$, por el contrario, el demandante se coloca exclusivamente en el terreno de la responsabilidad contractual y el tribunal está de acuerdo con esta caracterización, la demanda será desestimada cuando el juzgador entienda que las reglas contractuales no permiten acogerla. La pregunta es si, considerando el tribunal inaplicables los principios de la responsabilidad contractual, puede examinar la demanda desde el punto de vista extracontractual. La contestación afirmativa no violaría el principio del non-cumul, pero sí vulneraría el principio de congruencia. 
Por fin, el demandante puede formular su demanda de forma alternativa, esto es, tanto sobre la base de las normas de la responsabilidad contractual como en las de la extracontractual. Hipótesis en la que el tribunal opta por el régimen que le parece rectamente aplicable, pero desde luego moviéndose sólo dentro de él.

b) La otra fórmula posible es la de admitir que responsabilidad contractual y extracontractual puedan concurrir. La «concurrencia» (Anspruchskonkurrenz, cumul, concorso) significa que el demandante puede elegir libremente entre el régimen contractual y el extracontractual. En otras palabras, se le permite gozar de las ventajas de la calificación por la que opte.

Es el caso del Derecho alemán, en el que la víctima de una violación del contrato puede optar por demandar sobre las bases de la responsabilidad extracontractual, si un tercero en similar situación pudiera haberlo hecho.

Otro tanto ocurre en Italia, país en el que una creación jurisprudencial de constante aplicación determina que el perjudicado no sólo puede elegir entre los dos regímenes de responsabilidad el más favorable para hacer efectivo su derecho al resarcimiento, sino incluso acumular las ventajas de las dos distintas acciones de resarcimiento, en el sentido de recurrir a una cuando una circunstancia jurídica no permita valerse de la otra.

La jurisprudencia italiana ha dicho que «la pretensión del perjudicado puede encontrar su fundamento, además de en el precepto general del neminen laedere, también en el contrato, con la consecuencia de que frustrada una de las dos acciones por razones relativas a ella, como por ejemplo la prescripción, queda intacta la otra acción, fundada en los mismos presupuestos de hecho e igualmente dirigida a conseguir el resarcimiento del daño, sujeta a su propio plazo de prescripción». El fundamento de esta orientación jurisprudencial es la de que una misma conducta lesiona un interés que -además de encontrar tutela específica dentro de una relación existente entre dañado y dañador-, debe considerarse tutelado también, de forma general, por las normas sobre los actos ilícitos. Como dice la Corte di Cassazione, el concurso es posible cuando el hecho dañoso (contractual) sea lesivo «de los derechos absolutos, que corresponden al perjudicado, de no sufrir daño al honor, a la integridad personal y a la propiedad de la que es titular». Se considera que esta fórmula otorga la máxima tutela posible a la víctima.

Sucede lo mismo en Suiza, donde si un supuesto de hecho reúne las condiciones de responsabilidad contractual y extracontractual, se admite la concurrencia: en el mismo sentido de facultad de elección de aquella de las acciones que el actor estime más favorable.

Deschenaux y Tercier invocan al respecto un curioso argumento. Dicen que no hay nada en la ley que no permita afirmar que la víctima debería ser 
en este caso privada de las ventajas que le podría ocasionar una u otra acción. Por ello, añaden, es «normal» dejarle la posiblidad de elegir entre ellas e incluso intentar las dos, bien entendido que la admisión de una dejará a la otra sin objeto. La originalidad del argumento radica en tomar como punto de partida no lo que la ley permite, sino lo que la ley no prohíbe.

El Derecho angloamericano admite generalmente la concurrencia de reclamaciones, aunque en caso de conflicto entre las reglas aplicables al contract y al tort (por ejemplo, el comienzo del cómputo de la prescripción), los daños personales y los daños a la propiedad son casi siempre calificados por los tribunales como tortious.

Es frecuente que los autores cataloguen el sistema inglés, así como norteamericano, dentro de un tercer género, de rasgos difíciles de aprehender para juristas de mentalidad distinta de la del common law. Pero a los efectos que me ocupan no hay inconveniente en situar esos sistemas en el lugar en que ahora lo hago.

En Inglaterra, los tribunales dejan casi siempre a la víctima la posibilidad de colocarse en el terreno que le es más favorable; es decir, le dejan elegir libremente entre un régimen u otro. Pero téngase presente que como el common law no conoce un principio general análogo al de nuestro artículo 1.902 o al del 1.382 del Código francés (porque la responsabilidad nace de la infracción de un deber sancionado por un «tort»), se suele entender que hay hipótesis en que sólo debe aplicarse el law of torts.

\section{C) Posición actual del Tribunal Supremo español}

Frente a lo que ocurrió en el pasado, en que el Tribunal Supremo adoptó fórmulas rigoristas según las cuales la fundamentación jurídica de una demanda de responsabilidad (con lo que ello implica de explícita o tácita calificación) determinaba el éxito o fracaso de la demanda según la calificación que por su parte adoptara el juzgador, la más reciente jurisprudencia se orienta en una línea menos rigurosa y marcadamente inclinada a resolver con independencia de la fundamentación invocada por el demandante. Lo que ha determinado en buena medida un correlativo cambio de signo de las opiniones doctrinales (Pantaleón, en su comentario al artículo 1.902).

La última jurisprudencia permite afirmar que es posible la formulación alternativa de la responsabilidad contractual y de la extracontractual, esto es, que resulta factible reclamar al amparo de una u otra fundamentación o causa de pedir, de suerte que sean los tribunales los que apliquen una u otra calificación, según su criterio y al amparo del principio ius novit curia.

Pero no sólo eso, sino que basta con que el demandante proporcione al tribunal el «componente fáctico esencial de la acción ejercitada», esto 
es, la descripción de los hechos y su prueba, de suerte que quede clara su pretensión de resarcimiento, sin necesidad de vincularse (el propio actor) por una calificación determinada. La fundamentación jurídica de la demanda no vincula al tribunal, ni respecto de la que el actor dé a la relación litigiosa, ni respecto de las normas a aplicar. Dicho de otro modo, aunque el perjudicado haya fundamentado su demanda en normas de la responsabilidad extracontractual o de la contractual, exclusivamente, el tribunal podrá estimarla (siempre que los hechos aportados al proceso lo permitan), sin incurrir en incongruencia por cambio de la causa de pedir.

La sentencia de 26 de enero de 1984 llegó a declarar que «los tribunales no tienen necesidad ni obligación de ajustarse, en los razonamientos jurídicos que les sirven para motivar sus fallos, a las alegaciones de Derecho de las partes, y pueden basar sus decisiones en fundamentos jurídicos distintos, pues a ello les autoriza la regla que el aforismo iura novit curia encarna».

\section{Autores citados}

Razones que considero obvias me han movido a no introducir en esta ponencia aparato bibliográfico, tal y como de ordinario entendemos esta expresión. No obstante, no podía omitir la referencia de los autores citados en el texto.

Alvarez GonZÁlez, S.: «La ley aplicable a la responsabilidad precontractual en Derecho internacional privado», en R.E.D.I., vol. XLII (1990), 1, pp. 125-152. ANTUNES VARela, J.: Das obrigaçöes em geral, 7. a ed., Coimbra, 1991, 2 volúmenes. BANAKAS, E.: Tortious liability for pure economic loss: a comparative study, Atenas, 1989.

BERCOVITZ, A. y R.: Estudios jurídicos sobre protección de los consumidores, Madrid, 1987.

CARBOnNier, J.: Droit civil, 13. a ed., tomo IV, París, 1988.

Carrasco Perera, A.: «Comentario al artículo 1.107» en Comentarios al Código civil y compilaciones forales, dirigidos por Albaladejo, tomo XV, vol. $1{ }^{\circ}$, Madrid, 1989.

CAVANillas Múgica, S. y TAPIA Fernández, I.: La concurrencia de responsabilidad contractual y extracontractual (Tratamiento sustantivo y procesal). Madrid, 1992.

De ANGel YÁGüEz, R.: Tratado de responsabilidad civil, Madrid, 1993, y «La responsabilidad civil del médico y de las Administraciones sanitarias», ponencia elaborada para el II Congreso Derecho y salud, Granada, noviembre de 1993.

Deschenaux, H. y Tercier, P.: La responsabilité civile. 2. ${ }^{\text {a ed., Berna, } 1982 .}$

DIAS, R.W.M. y MARKESINIS, B.S.: Tort Law. 2. a ed., Oxford, 1989.

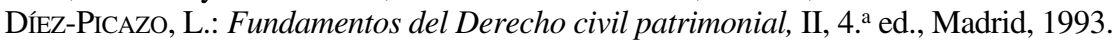


FLEMING, J.G.: «Liability for services in American Law», ponencia presentada en el Coloquio Liability for services rendered, celebrado en Lausana los días 1 a 3 de setiembre de 1993, bajo la organización de The International Association of Legal Sciences.

GAROFAlO, C.: Il manuale della responsabilità civile e penale del banchiere e del bancario, Rovereto, 1992.

GIARDINA, F.: Responsabilità contrattuale e responsabilità extracontrattuale (Significato attuale di una distinzione tradizionale), Milán, 1993.

GIESSEN, D.: «Liability for the provision of services under German Law», ponencia presentada en el Coloquio Liability for services rendered, celebrado en Lausana los días 1 a 3 de setiembre de 1993, bajo la organización de The International Association of Legal Sciences.

Heuston, R.F.V. y Fuckley, R.A.: Law of Torts (SAlmond y Heuston), 20. ${ }^{\text {e ed., }}$ Londres, 1992.

HuET, J.: «La responsabilité du fournisseur de services, en particulier dans le cadre de l'activité des proffesions libérales», ponencia presentada en el Coloquio Liability for services rendered, celebrado en Lausana los días 1 a 3 de setiembre de 1993, bajo la organización de The International Association of Legal Sciences y «Responsabilité civile. Considérations générales sur la distinction des responsabilités contractuelles et délictuelles», en Revue trimestrielle de droit civil, 1985.

KeMElmaJER DE CARLuCCI, A.: «La responsabilidad civil en los albores del siglo XXI (la responsabilidad civil en el proyecto de reformas del Código civil de 1993)», en Jurisprudencia argentina, número 5.827, mayo de 1993, pp. 2-13.

MEHREN, A.V.: «The formation of contracts», en International Encyclopedia of Comparative Law, VII (Contracts in general, cap. 9) y «Methods of limiting damages», en la misma obra y en el mismo tomo, cap. 16 (Remedies for breach of contract).

MERZ, H.: «Droit des obligations», en el Traité de droit privé suisse, tomo I, Friburgo, 1993.

PANTALEón, F.: «El sistema de responsabilidad contractual (Materiales para un debate)», en $A D C$, julio-setiembre 1991, pp. 1.019-1.091 y Comentario del Código civil, Madrid, 1991, II, comentario al artículo 1902.

Posch, W.: «Contract and Tort in traditional Austrian Law», ponencia presentada en el Coloquio Liability for services rendered, celebrado en Lausana los días 1 a 3 de setiembre de 1993, bajo la organización de The International Association of Legal Sciences.

RoDOtÀ, N.: Il problema della responsabilità civile, Milán, 1964.

Rojo FERNÁNDEZ-Río, A.: La responsabilidad civil del fabricante, Zaragoza, 1984.

Stoll, H.: «Consequences of liability: Remedies», en International Encyclopedia of Comparative Law, XI-2 (Torts), cap. 8.

TERCIER, P.: Le nouveau droit de la personnalité, Zurich, 1984.

TuNC, A.: «The concept of tort and the delimitation of the Law of Tort», en International Encyclopedia of Comparative Law, XI-1 (Torts), cap. 1 (Introduction).

VINEY, G.: «La responsabilité: conditions», en el Traité de droit civil dirigido por GHESTIN, tomo IV, París, 1982.

VisintinI, G.: I fatti illeciti, I, Padua, 1987 y voz «Responsabilità contrattuale ed 
extracontrattuale», en Enciclopedia giuridica Treccani, vol. XXVI, Roma, 1991.

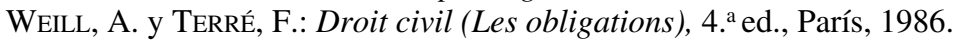

WEIR, T.: «Services in England», ponencia presentada en el Coloquio Liability for services rendered, celebrado en Lausana los días 1 a 3 de setiembre de 1993, bajo la organización de The International Association of Legal Sciences y «Multiple grounds of claim» en International Encyclopedia of Comparative Law, XI-2, (Torts), cap. 12 (Complex Liabilities).

YZQuierdo TOlsada, M.: Responsabilidad civil contractual y extracontractual, I, Madrid, 1993.

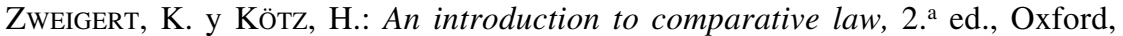
1987. 